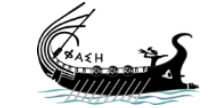

journal.phaselis.org
PHASELIS

Issue IV (2018)
Disiplinlerarası Akdeniz Araştırmaları Dergisi

Journal of Interdisciplinary Mediterranean Studies

\title{
Andriake Limanından Ele Geçen DSD Grubu / Kıbrıs Sigillataları Işığında Lykia'nın Doğu Akdeniz ile Deniz Ticareti
}

\author{
Uncovered ESD Group / Cyprus Sigillata from Andriake Port \\ in the Light of Maritime Trade of Lykia With Eastern \\ Mediterranean
}

\section{Banu ÖZDILEK}

The entire contents of this journal, Phaselis: Journal of Interdisciplinary Mediterranean Studies, is open to users and it is an 'open access' journal. Users are able to read the full texts, to download, to copy, print and distribute without obtaining the permission of the editor and author(s). However, all references to the articles published in the e-journal Phaselis are to indicate through reference the source of the citation from this journal.

Phaselis: Journal of Interdisciplinary Mediterranean Studies is a peer-reviewed journal and the articles which have had their peer reviewing process completed will be published on the web-site (journal.phaselis.org) in the year of the journal's issue (e.g. Issue III: JanuaryDecember 2017). At the end of December 2016 the year's issue is completed and Volume IV: January-December 2018 will begin.

Responsibility for the articles published in this journal remains with the authors.

Citation B. Özdilek, "Andriake Limanından Ele Geçen DSD Grubu / Kıbrıs Sigillataları Işığında Lykia'nın Doğu Akdeniz ile Deniz Ticareti”. Phaselis IV (2018) 57-77. http://dx.doi.org/10.18367/Pha.18004

Received Date: 29.06.2017 | Acceptance Date: 20.12.2017

Online Publication Date: 14.02.2018

Editing Phaselis Research Project www.phaselis.org 


\title{
Andriake Limanından Ele Geçen DSD Grubu / Kıbrıs Sigillataları Işığında Lykia'nın Doğu Akdeniz ile Deniz Ticareti
}

\author{
Uncovered ESD Group / Cyprus Sigillata from Andriake Port in the Light of Maritime \\ Trade of Lykia With Eastern Mediterranean
}

\author{
Banu ÖZDILEK*
}

\begin{abstract}
Öz: Andriake'de 2009 yılında gerçekleştirilen kazılar sırasında, Lykia Bölgesi'nde ilk kez bir sinagog yapısı ortaya çıkarılmıştır. Bu yapı kentte Granarium'un önündeki ana kaya tabanlı alana inşa edilmiştir. Sinagog MS V-Vı yüzyıla ait olup, kazılar esnasında, yapının apsis bölümünden çok yoğun olarak Hellenistik, Roma ve Bizans dönemlerine ait, seramik parçalar ele geçmiştir. Sinagogun inşası sırasında zemindeki düzensiz, büyük ana kaya kütleleri arasındaki boşlukların tesviyesi için, kentte bulunan bir seramik çöplüğünden atık seramik getirilerek dolgu yapılmış olduğu düşünülmektedir. Apsis çukurunda bulunan ana kaya arasındaki boşlukların toprak yerine atık seramikle doldurulmasının nedeni, zeminin daha çabuk ve daha dayanıklı biçimde, tesviyeye uygun olmasıdır. Seramikler kentin seramik atık alanından getirildiği için belli bir stratigrafik bütünlük göstermemektedir. Apsis içerisindeki seramiklerin tipolojik, hamur-astar ve kronolojik olarak değerlendirilmesi sonucunda yoğunluğun doğu sigillatalardan oluştuğu ortaya konmuştur. Lykia Bölgesi'nde kazı çalışması yürütülen az sayıda liman kenti bulunur. Bunlardan biri olan Andriake'deki seramiklerin çalışılması, kenttin ticari bağlantılarını aydınlatılması açısından da son derece önemlidir. Bu çalışmada alandan ele geçen en yoğun ikinci seramik grubu olan Kıbrıs sigillataları değerlendirilmiştir. Andriake liman kenti özelinde yapılmaya başlanan seramik yayınlarıyla, kent ve Lykia Bölgesi'nin deniz ticareti, seramiklerin dağıımı, formlarının analojisinin çıkarılması açısından önemlidir.
\end{abstract}

Anahtar sözcükler: Lykia, Andriake-Myra, Terra Sigillata, Kıbrıs Sigillataları. DSD Grubu Sigillataları

Abstract: During the excavations in Andriake Synagogue, belonging to the $\mathrm{V}^{\text {th }}$ and $\mathrm{VI}^{\text {th }}$ centuries, fragments of well preserved ceramics were found intensively belonging to Hellenistic, Roman and Byzantine periods in the apse section of the structure. The synagogue was built on the main rock-base area in front of the Granarium in the city. For levelling the gaps between the major bedrock masses, apart from the land fill, large, nearly whole ceramic pieces are thought to be used in filling more quickly. It is beleived that these ceramic ware was brought from a ceramic waste area close to synagogue and used in filling. Along with the study of the ceramics in the apse, it is observed that especially the imported sigillatas are particularly intense. The study of the ceramics of Andriake has a great importance in terms of illuminating the trade in the port cities due to its one of the few port cities in Lycia which has been excavated so far. As a result of dating the findings, it is seen that, starting from $\mathrm{I}^{\text {st }}$ century $\mathrm{BC}$ to $\mathrm{VI}^{\text {th }}$ century AC, a ceramics trade with Cyprus took place. From the $3^{\text {rd }}$ century AC onwards, Cypriot sigillatas have left their place in cypriot red slip ceramics. It is aimed to uncover the commercial connections of the port settlement by studying the ceramics of different types of doughs and forms found in Andriake, the international port city of Lycia.

Keywords: Lykia, Andriake-Myra, Terra Sigillata, Cypriot Sigillatas, ESD Group Sigillata

* Yrd. Doç. Dr., Mustafa Kemal Üniversitesi, Fen-Edebiyat Bölümü, Arkeoloji Bölümü, Hatay, ozdilek.banu@gmail.com 
Andriake, Lykia Bölgesi'ndeki büyük kapasiteli liman yerleşimlerinden biridir. Kentteki yapıların büyük bir çoğunluğu liman işlevi ile alakalıdır. Bu çalışmada 2009 yılında kazılmış olan Sinagog yapısının apsis bölümünden 190 adet sigillata örneğinden, Doğu Sigillataları içerisinde yer alan Kıbrıs seramikleri DSD grubu değerlendirilmiştir.

Sigillataların ele geçtiği, sinagog yapısı MS X. yüzyıla ait olup (Fig. 4, Fig. 5), yapının inşası sırasında apsis kısmı ana kaya üzerine inşa edilen yapının tesviyesi için, kentin seramik atık alanından getirilen seramik malzeme ile dolgu yapıımış olduğu ortaya çıkmıştır (Fig. 6a, Fig. 6b). Dolayısıyla apsis çukurundan ele geçen seramikler homojen olmayıp, belli bir stratigrafiye sahip değildir. Bu alandan ele geçen seramik grupları dönemleri, formlarına göre ayrılarak tarafımdan yayınlanmıştır ${ }^{1}$. Bu alandan ele geçen seramikler Hellenistik Dönemden Bizans Dönemi'ne kadar devam etmektedir.

Terra Sigillata terminolojisi, kırmızımsı kahverengi seramikler için, arkeolojik literatüre Zahn tarafından 19. yüzyılda sokulmuştur². Terra sigillatalar, MÖ II. yüzyılın ikinci yarısından itibaren Batı Akdeniz, Anadolu ve Doğu Akdeniz'de kırmızı, parlak, sinter astarlı seramikler üretilmeye başlanır. Roma Dönemi'nde en sık kullanılan masa kaplarıdır. İlk kez üretildiği coğrafya Doğu Akdeniz olarak kabul edilir. Bu seramiklerin ilk çalışılmaya başlandığı dönemde buluntu yerlerine göre isimlendirilmişlerdir, örneğin "Samian Ware ${ }^{3}$, Pergamon Ware" gibi. Daha sonraları, Doğu Sigillata A, B, C, D gibi alfabetik kodlama da üretim yerleri ve hamur-astar özelliklerine göre adlandırılmışlardır ${ }^{4}$. Bu grupların üretim tarihlerinde ve formlarında farklııklar bulunmaktadır. Form olarak kimi zaman benzer formların her grupta tercih edilmiş olduğu görülmektedir.

Doğu Sigillata D Grubu (Kıbrıs Sigillatası): Hamur rengi ${ }^{5}$ açık pembemsi kahverengiden, koyu kırmızımsı kahverengiye kadar uzanmaktadır. Hamur yapısı ince taneciklidir. Kireç ve mika katkıları bulunur. Munsell kataloğundaki karşıllğı ${ }^{6} 2,5$ YR 5/8, 6/4, 6/6, 6/8, 7/6, 7/8; 7,5 YR 6/3, 7/6, 8/6; 5 YR 5/6, 6/4, 6/6, 7/4, 7/6, 7/8; 10 R 4/8, 5/6) dır. Astarı ise hamur yapısından birkaç ton daha koyu olup, parlak astarı kimi zaman metal parlaklığına sahip olabilmektedir. Astar renginin Munsell kataloğundaki karşılığı (2,5 YR 4/4, 4/3, 4/6, 4/8, 5/6, 5/8, 6/8; 10 R 4/4, 4/6, $5 / 6,5 / 8)^{\prime}$ dir.

Kıbrıs sigillataları Hayes ${ }^{7}$ tarafından tanımlanmış olup, Paphos örnekleri ışığında tipolojisi oluşturulmuştur ${ }^{8}$. Kenyon'un Sigillata terminolojisinde DSD olarak kodlanmıştır ${ }^{9}$. DSD grubunun ele geçtiği yoğun buluntu grubuna göre, üretim merkezleri üzerine farklı görüşler bulunmaktadır. Kıbrıs'ta Ayios Philon, Kornakiti, Paphos, Polis, Soli, olduğu yönünde görüşler bulunur, kil

Myra-Andriake Kazıları başkanı, hocam Prof. Dr. Nevzat Çevik'in malzemenin çalışılmasıyla ilgili izini için ve Myra-Andriake kazılarına büyük emek veren ekip arkadaşlarıma teşekkür ederim. Bu çalışmaya fikir ve görüşleriyle katkıda bulunan Yrd. Doç. Dr. Çilem Uygun'a teşekkür ederim.

1 Özdilek 2015, 89-117; Özdilek 2016, 217-265; Özdilek 2017, 337-395; B. Özdilek tarafından "The Uncovered Oil Lamps From Andriake Synagogue" isimli bildiri, 3- 5 Mart 2011 tarihinde, Italya Catania Üniversitesi'nde düzenlenmiş olan 15. SOMA Uluslararası Akdeniz Arkeolojisi sempozyumunda sözlü olarak sunulmuştur.

Zahn 1904, 447.

Zahn 1904, 447; Waagé 1937: 53.

Kenyon 1957, 282.

Kıbrıs sigillatalarının hamur ve astar özellikleri için bkz. Fırat 1999, 21-22. Munsell katalog renkleri ise Patara Tepecik Doğu Nekropolü'nde tespit edilen ithal DSD örneklerine göre düzenlenmiştir.

Andriake'den ele geçen Kıbrıs sigillatalarının renklerine göre Munsell kataloğundaki karşılıkları bulunmuştur. J. W. Hayes, "Cypriot Sigillata", RDAC 1967, 65-77.

Hayes 1985, 79-91.

Kenyon 1957, 282. 
analizlerine göre Nea Paphos'da da üretim olduğu bulunmuştur ${ }^{10}$. Kıbrıs dışında İsrail'de Nabatya Bölgesi'ndeki Avdat (Oboda) yerleşiminde ele geçen seramik üretim fırınları ve seramiklerin hamur-astar özellikleri nedeniyle burada da yerel üretim olduğu ileri sürülmekte$\mathrm{dir}^{11}$. DSD grubu seramiklerinin üretim merkezleri arasında Güney Filistin Bölgesi ve Anadolu'nun Güney kıyıları Gunneweg tarafından önerilmektedir ${ }^{12}$.

Sigillatalar içerisinde en erken ortaya çıkan grup DSA grubu olup, önceleri bu seramikler Pergamon seramikleri olarak adlandırılır. Kıbrıs seramikleri ise, bu iki gruptan hemen sonra MÖ I. yüzyıl başında Kıbrıs'ta ortaya çıkmıştır ${ }^{13}$. Kıbrıs'ta DSD üretimi MÖ I. yüzyıl başında başlamasına rağmen, seramiklerin ticari yayılımı MÖ I. yüzyılın ikinci yarısında başlayarak, MS I. yüzyılın birinci yarısına kadar sürmektedir ${ }^{14}$. Üretim MS II. yüzyılın ikinci yarısına kadar sürmüş olup, MS III. yüzyıldan itibaren astar kalitesinde bir düşüş yaşanmış olup, Geç Roma Dönemi özelliği olan kırmızı astarlı seramik özelliğinde Kıbrıs seramikleri üretimine geçilmiştir. Ticaretle birlikte yayıIım alanı başta Doğu Akdeniz ${ }^{15}$ ile İsrail ${ }^{16}$, Kuzey Afrika ${ }^{17}$, Mısır $^{18}$, Pamphylia ${ }^{19}$, Lykia $^{20}$, Girit $^{21}$, Batı Anadolu ${ }^{22}$, Kıta Yunanistan'da ${ }^{23}$ İtalya'da ${ }^{24}$ ele geçmiş olup, bu coğrafyadan anlaşıldığı üzere yayılım alanı başta Akdeniz Bölgesi olmak üzere, zamanla genişlemiş olup, DSA grubu ile benzer bir yayılım alanı göstermektedir.

Kıbrıs sigillataları çarkta şekillendirilen, sade profil özellikleri gösterirler. Kap formları içerisinde en çok farklı form ve bezemelere sahip krater formları ile emzikli testi formları diğer gruplarda az rastlanan ya da görülmeyen formlardır.

\section{Tipolojik Değerlendirme}

Apsis alanından toplam 24 adet DSD seramiği ele geçmiştir. 4 formda 10 tabak, 2 formda 2 kase, 5 formda 9 krater, 1 formda 3 testi örneği Hayes'in tipoloji çalışmasına göre değerlendirilmiştir (Genel olarak bkz.: Hayes 1985). Seramikler üzerinde rulet ve çizgisel bezemeler bulunur.

\section{DSD Grubu Tabaklar}

Tabak Form 1-Hayes Paphos 4 B (Kat. No. T. 1, Fig. 1): Dışa taşkın, yatay dudak, yumuşak ya da keskin bir profille kaideye yönelen kısa gövde ve alçak halka kaideli sığ tabak formudur. Gövdeden tabana geçiş köşeli bir profille vurgulanmış olup, alçak geniş profilli kaidesi vardır. Hayes, bu formu ağız ve kaide profillerindeki farklılıklara göre A-B olmak üzere iki alt gruba ayırmış ve form gelişimi yakalamaya çalışmıştır. A grubu içerisinde değerlendirilen içe dönük ağızlı ve kaidesi yivli örnekler MÖ ।. yüzyıl sonuna tarihlenmiştir. Benzer örnekler Atina ${ }^{25}$,

10

11

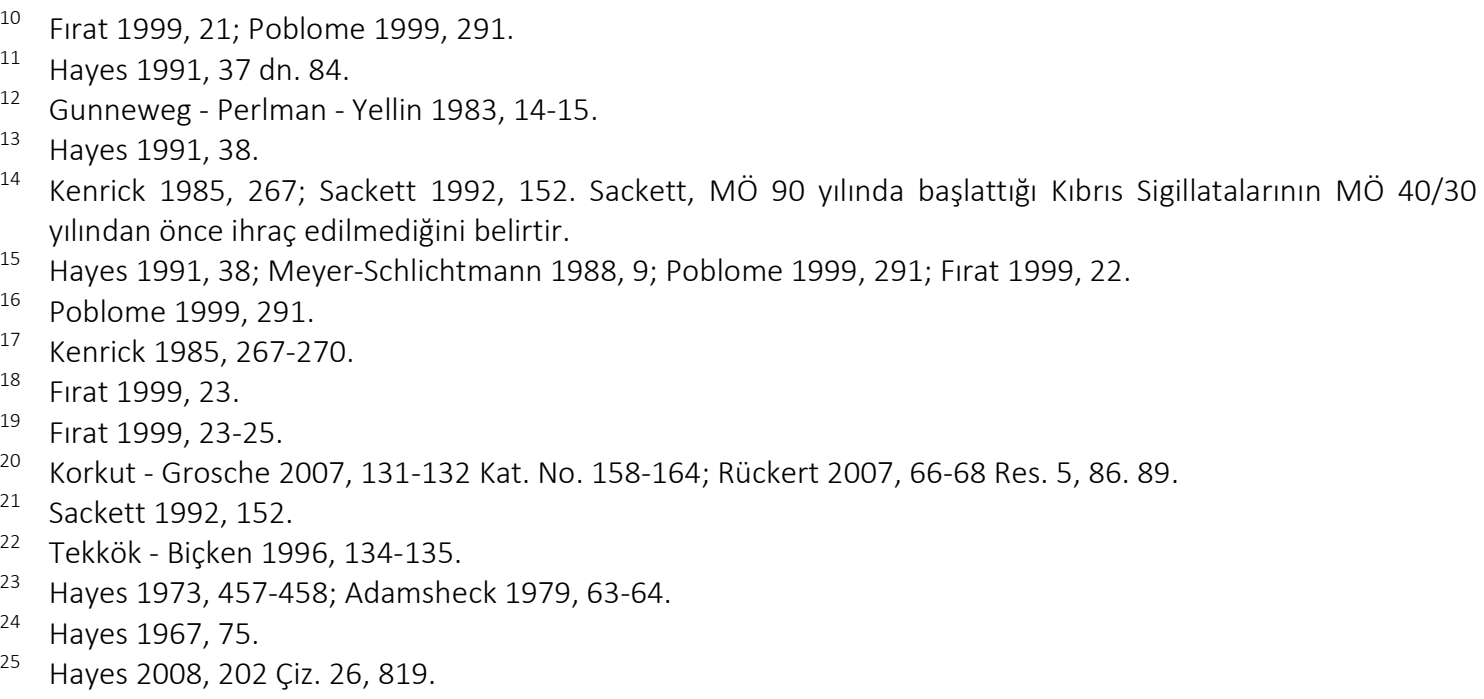


Knossos $^{26}$, Tel Anafa ${ }^{27}$, Perge ${ }^{28}$ ve Patara'dan ${ }^{29}$ ele geçmiştir. Andriake örneği, benzer örnekler ışığında MS I. yüzyıl ortasına tarihlenir.

Kat. No.: T. 1, Fig. 1.

Ölçüler: A. Ç.: $30 \mathrm{~cm}$ Y.: $3 \mathrm{~cm}$ K.Ç.:.

Hamur Rengi: 7.5 YR 8/6 reddish yellow.

Astar Rengi: 2.5 YR 5/8 red.

Dönemi: MS I. yüzyıl ortası.

Karşılaştırma: Uygun 2011, Lev. 36, Kat. No.

538; Hayes 1985, 81 Lev. XVIII 8-9; Hayes 1991,

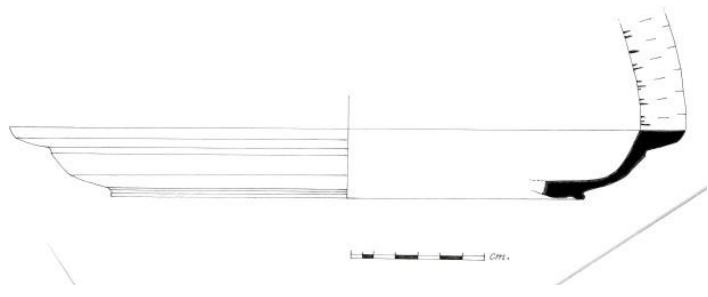

39 Res. XVIII 4. 1-2; Hayes 2008, 202 Çiz. 26, 819.

Tabak Form 2 - Hayes Paphos $10^{30}$ (Kat. No. T. 6-10, Fig. 1): Dışa taşkın yuvarlak kesitli dudak, dışbükey gövde, alçak, halka kaide zeminden yükseltilmiş olarak şekillendirilmiş tabak formudur. Andriake'den bu gruba giren 4 örnek bulunmakta olup, tabakların ayrıntıda farklı profil özellikleri bulunmaktadır. Benzer örnekler Paphos'tan, Atina ${ }^{31}$, Knossos $^{32}$, Tarsus $^{33}$, Perge $^{34}$, Patara $^{35}$, Trysa $^{36}$ ve Berenice'den ${ }^{37}$ ele geçmiştir. Hayes' e göre bu grupta değerlendirilen örnekler MÖ I. yüzyıl sonu ile MS ı. yüzyılın ilk yarısına, kalın cidarlı örnekler ise, MS I. yüzyılın ikinci yarısına tarihlenir.

Kat. No.: T. 2, Fig. 1.

Ölçüler: A.C.: $18,5 \mathrm{~cm}$ Y.: $5 \mathrm{~cm}$ K.Ç.:

Hamur Rengi: 2,5 YR 7/4 - light reddish brown

Astar Rengi: 2,5 YR 5/6- red

Dönemi: MÖ I. yüzyılın ikinci yarısı.

Karşılaştırma: Hayes 1986, Form P11; Hayes 1967, 72

Form 10; Williams 1989, 5 No. 21 Lev. 2; Oransay

2012, Çiz. 2, Kat. No. 13

Kat. No.: T. 3, Fig. 1.

Ölçüler: A.Ç.: $16 \mathrm{~cm}$ Y.: $4 \mathrm{~cm}$ K.Ç.:

Hamur Rengi: 5 YR $7 / 6$ - reddish yellow.

Astar Rengi: 2,5 YR 5/8 - red

Dönemi: MÖ I. yüzyıl sonu ile MS I. yüzyılın birinci yarısı.

Karşılaştırma: Jones 1950, 272 Res. 203, 768. 770.

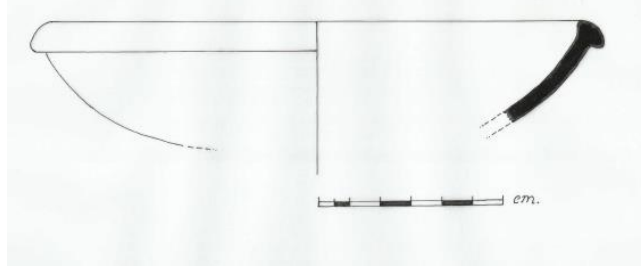

771; Hayes 1985, 82 Lev. XIX 1; Kenrick 1985, 268 Res. 49 FW 375-376; Hayes 2008, 202 Çiz. 26, 817; Yılmaz 2008, 109 Lev. LXIII 21-22. 24-25; Uygun 2012, Kat. No. 560.

6 Sackett 1992, 251 Lev. 192, 29.

27 Slane 1997, 376 Lev. 36 FW575.

28 Firat 1999, 23-25, Lev. 32, 71-72.

29 Uygun 2011, 81, Kat. No. 538.

30 Hayes 1985, 82 Lev. XIX 1.

31 Hayes 2008, 202 Çiz. 26, 817.

32 Sackett 1992, 152. 206. Sackett, C 2 açmasında Hayes P 10 grubundan birkaç küçük parçanın bulunduğunu belirtmesine karşın yayında örneklerin çizimi yer almamaktadır.

33 Jones 1950, 272 Res. 203, 768. 770. 771.

34 Firat 1999, 24 Lev. 30, 55-56.

35 Uygun 2011, Kat. No. 567-578.

36 YIImaz 2008, 109 Lev. LXIII 21-22. 24-25.

37 Kenrick 1985, 268 Res. 49, 375-376. 
Kat. No.: T. 4, Fig. 1.

Ölçüler: A. Ç.: cm Y.: 4 cm K.Ç.:20,5 cm.

Hamur Rengi: 2,5 YR 6/6 - red

Astar Rengi: 2,5 YR 4/8 - light red

Dönemi: MÖ I. yüzyıl sonu-MS I. yüzyılın birinci yarısı.

Karşılaştırma: Uygun 2011, Lev. 38, Kat. No. 566;

Jones 1950, 272 Res. 203, 768. 770. 771; Hayes 1985,

82 Lev. XIX 1; Kenrick 1985, 268 Res. 49 FW 375-376; Hayes 2008, 202 Çiz. 26, 817; Yılmaz 2008, 109 Lev. LXIII 21-22. 24-25.

Kat. No.: T. 5, Fig. 1.

Ölçüler: A. Ç.: $21 \mathrm{~cm}$ Y.: $4 \mathrm{~cm}$ K.Ç.: $13 \mathrm{~cm}$.

Hamur Rengi: 5 YR $7 / 8$ - reddish yellow.

Astar Rengi: 5 YR 6/8 - reddish yellow.

Dönemi: MÖ I. yüzyıl sonu ile MS I. yüzyılın birinci yarısı.

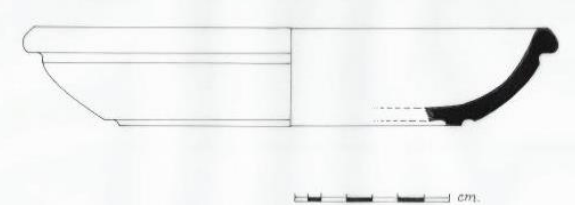

Karşıllaştırma: Jones 1950, 272 Res. 203, 768. 770. 771; Hayes 1985, 82 Lev. XIX 1; Kenrick 1985, 268 Res. 49 FW 375-376; Hayes 2008, 202 Çiz. 26, 817; Yılmaz 2008, 109 Lev. LXIII 21-22. 24-25; Uygun 2012, Kat. No. 565.

Tabak Form 3- Hayes Paphos 12 (Kat. No. T. 11, Fig. 11): İ̧̧e kapanan ağız, dışa taşkın yuvarlak kesitli dudak, kaideye doğru daralan düz gövde ve alçak halka kaideli tabak formudur. Dudak profilinde küçük farklar bulunur bazı örneklerde dudak profili sivri, kimi örnekte yuvarlaktır. Hayes bu grubu MS I. yüzyılın ikinci yarısı ile MS II. yüzyılın birinci yarısına tarihlemektedir. Benzer örnekler Atina ${ }^{38}$, Tel Anafa ${ }^{39}$, Perge ${ }^{40}$ ve Patara'da ${ }^{41}$ ele geçmiştir. Benzer örnekler ışığında, Andriake örnekleri MS I. yüzyılın ikinci yarısına tarihlenir.

Kat. No.: T. 6, Fig. 1.

Ölçüler: A. Ç.: $24,5 \mathrm{~cm}$ Y.: $5 \mathrm{~cm}$ K.Ç.:

Hamur Rengi: 5 YR 7/8 reddish yellow.

Astar Rengi: 5 YR 6/8 reddish yellow.

Dönemi: MS I. yüzyılın ikinci yarısı.

Karşılaştırma: Hayes 1991, Lev. 18, Kat. No. 12; Uygun

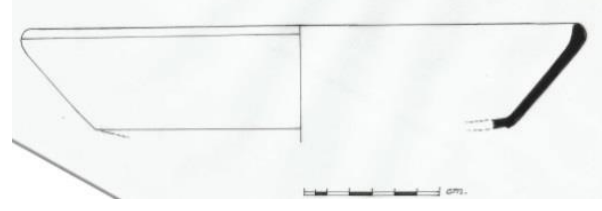
2011, Lev. 39, 583.

Tabak Form 4-Hayes Paphos 4-6 Kaide örnekleri (Kat. No. T. 7-10, Fig. 1): Dış konturu düz, kare kesitli, yivli kaide örnekler değerlendirilmiştir. Ait olduğu form grubu tespit edilemeyen kaideler, genel profil özellikleriyle DSD tipolojisindeki Paphos 4-6 formlarıla benzerlik gösterir. Patara'dan da ele geçen benzer kaideler ışığında ${ }^{42}$, Andriake örnekleri MS I. yüzyıla tarihlenir.

Kat. No.: T. 7, Fig. 1.

Ölçüler: A. Ç.: $\mathrm{cm}$ Y.: $2 \mathrm{~cm}$ K. Ç. : $16 \mathrm{~cm}$.

Hamur Rengi: 2.5 YR 6/6 - light red.

Astar Rengi: 10 R 5/6 - red.

Dönemi: MS I. yüzyılın birinci yarısı.

Karşılaştırma: Hayes 2008, Lev. 2, Kat. No. 21.

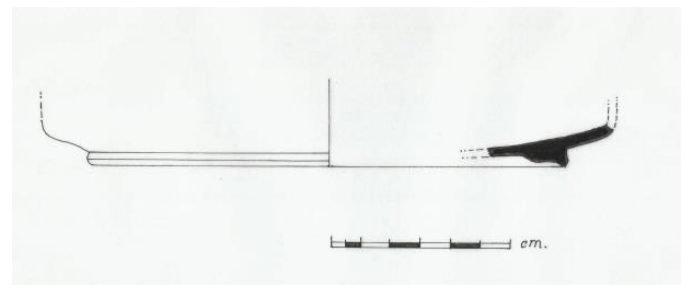

38 Hayes 2008, 202 Çiz. 26, 818.

39 Kenrick 1985, 269 Res. 49, 378. 1-2.

40 Firat 1999, 25 Lev. 30, 51.

41 Uygun 2011, Kat. No. 587; Uygun 2011, Kat. No. 583.

42 Uygun 2011, 81, Kat. No. 546. 
Kat. No.: T. 8, Fig. 1

Ölçüler: A. C..: cm Y. :2,5 cm K. Ç.:23,5 cm.

Hamur Rengi: 2,5 YR 6/6 - light red.

Astar Rengi: 10 R 5/8 red.

Form: Yumuşak bir profille kaideye yönelen gövde, yuvarlak kesitli, altında iç bükey profil

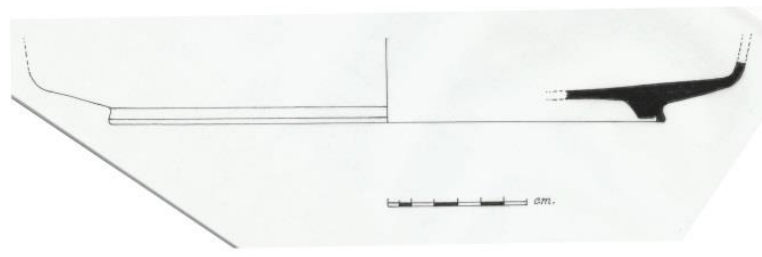
bulunan alçak halka kaide.

Dönemi: MS I. yüzyılın birinci yarısı.

Karşılaştırma: Hayes 2008, Lev. 2, Kat. No. 21.

Kat. No.: T. 9, Fig. 1.

Ölçüler: A.Ç.: cm Y.: $3 \mathrm{~cm}$ K.Ç.: $20 \mathrm{~cm}$.

Hamur Rengi: 2.5 YR 6/6 - light red.

Astar Rengi: 10 R 5/8 red.

Form: Yumuşak bir profille kaideye yönelen gövde, yuvarlak kesitli, altında iç bükey profil bulunan alçak halka kaide.

Dönemi: MS I. yüzyılın birinci yarısı.

Karşılaştırma: Hayes 2008, Lev. 2, Kat. No. 21.

Kat. No.: T. 10, Fig. 1.

Ölçüler: A.Ç.: cm Y. : 2 cm K.Ç.:18 cm.

Hamur Rengi: 2.5 YR 6/6 - light red.

Astar Rengi: 10 R 5/6 - red.

Form: Yumuşak bir profille kaideye yönelen gövde, yuvarlak kesitli, altında iç bükey profil bulunan alçak halka kaide.

Dönemi: MS I. yüzyılın birinci yarısı.

Karşılaştırma: Hayes 2008, Lev. 2, Kat. No. 21.

\section{DSD Grubu Kase}

Kase Form 1 - Paphos $22 \mathrm{~A}^{43}$ (Kat. No. K. 11, Fig. 2): Iç̧e dönük ağız, sivri uçla sonlanan üçgen kesitli dışa taşkın dudak, dış bükey, yuvarlak gövde profilli kase örneğidir. Bu kaseler cidar kalınlığına göre iki grupta değerlendirilirler. Andriake'den ele geçen ince cidarlı bu örnek $A$ grubundadır. Benzer örnekler Samaria, Tarsus ${ }^{44}$, Soli, Nessena, Patara'dan ${ }^{45}$ ve Nabatia Bölgesi'nden ele geçmiş olup, MÖ I. yüzyıl sonu ile MS 50 yılları arasına tarihlenmektedir.

Kat. No.: K. 11, Fig. 2.

Ölçüler: A. Ç.: $12 \mathrm{~cm}$ Y.: $3 \mathrm{~cm}$ K.Ç.:

Hamur Rengi: 2,5 YR 7/6 light red

Astar Rengi: 2,5 YR 5/8 - red

Form: İçe dönük ağız, sivri uçla sonlanan dışa taşkın üçgen profilli dudak, kaideye doğru dar bir açıyla kapanan gövde. Gövdenin en geniş yeri dudağın

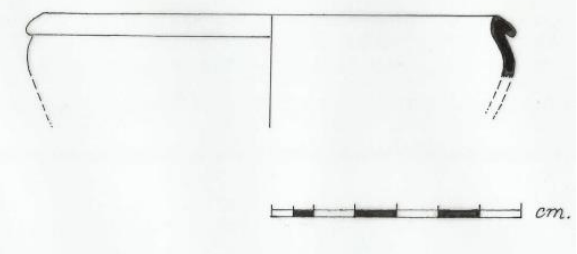
hemen altındadır.

43 Hayes 1985, 84-85 Lev. XIX 14-15.

44 Jones 1950, 250 Res. 195, 524.

45 Uygun 2011, Kat. No. 617. 
Dönemi: MÖ I. yüzyıl sonu ile MS I. yüzyılın birinci yarısı.

Karşılaştırma: Hayes 1985, 84-85 Lev. XIX 14-15; Kenrick 1985, 269 Res. 49, 380; Slane 1997, 376 Lev. 36 FW 579; Uygun 2011, Lev. 41, Kat. No. 617.

Kase Form 2-Paphos $20^{46}$ (Kat. No. K. 12, Fig. 2): İçe dönük ağız, gövdeyle bütünlük gösteren yuvarlak uçla sonlanan dudak, kaideye doğru daralan gövde profilli minyatür kâse formudur. İçe dönük ağız profilli kâseler Hellenistik gelenekte ${ }^{47}$ üretilmiş olduğu için Hayes tarafından MÖ I. yüzyıl başına tarihlenirler. Sigillata grupları içerisinde bu form ilk kez DSA grubunda görülmüştür ${ }^{48}$. Benzer örnekler Paphos ve Patara'dan ele geçmiştir ${ }^{49}$. Bu örnekler ışığında bu kâse formu MÖ ı. yüzyıl başına tarihlenir. Kıbrıs üretimi sigillata formları içerisinde erkene tarihlenen bu örneğin Lykia'da ele geçmesi, daha önceden önerildiği üzere Kıbrıs ile Lykia bölgesinin MÖ I. yüzyılın ortasında başlatılan ticaret tarihinin ${ }^{50}$, MÖ I. yüzyıl başına çekilmesine neden olmuştur. Lykia Bölgesi'nde Patara ile Andriake limanlarının bu tarihlerde Kıbrıs ile ticari ilişkilerinin olduğunu göstermektedir.

Kat. No.: K. 12, Fig. 2.

Ölçüler: A. Ç.: 8,5 cm Y.: $3 \mathrm{~cm} \mathrm{K.Ç.:}$

Hamur Rengi: 2,5 YR 7/6 light red.

Astar Rengi: 2,5 YR 5/8 - red.

Form: Süzgeçli sürahi. Sürahinin dikey dışa taşkın bir dudak profili vardır. S kıvrımı çizen huni formundadır.

Dönemi: MÖ I. yüzyıl başı.

Karşılaştırma: Uygun 2011, Lev. 41, Kat. No. 621; Hayes

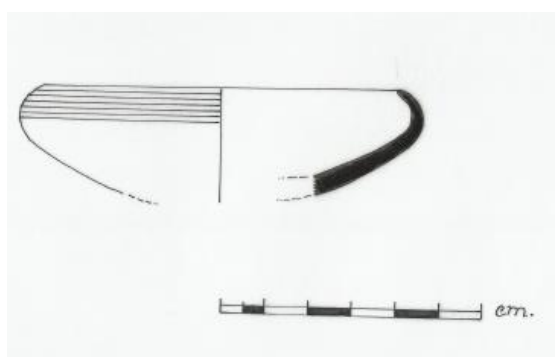

1985, Lev. LXX, Kat. No. 12; Hayes 1991, Lev. XX, 12, O 5256.

\section{DSD Grubu Kraterler}

Krater Form 1 -Hayes Paphos $36^{51}$ (Kat. No. K. 13, Fig. 2): Dışa açılan, aşağıya sarkık, yuvarlak bitimli dudak, kaideye doğru daralan yuvarlak gövdesi olan krater formudur. Dudağın altında, gövde üzerinde profiller bulunmaktadır. Kat. No. 22 no. lu örneğin dudağının altında yukarı doğru kulp bulunur. Benzer örnekler kısıtlı olup, Paphos ve Patara'dan ${ }^{52}$ ele geçmiştir. Bu örnekler ışığında MÖ I. yüzyıl ortasına tarihlenir.

Kat. No.: K. 13, Fig. 2.

Ölçüler: A.Ç.: 24, $5 \mathrm{~cm}$ Y.: 3,5 cm K.Ç.: Hamur Rengi: 2,5 YR 6/8 - light red

Astar Rengi: 2,5 YR 4/8 - red

Form: Dik ağız, yuvarlak bitimli dışa taşkın ve

aşağıya sarkık dudak içbükey bir profille

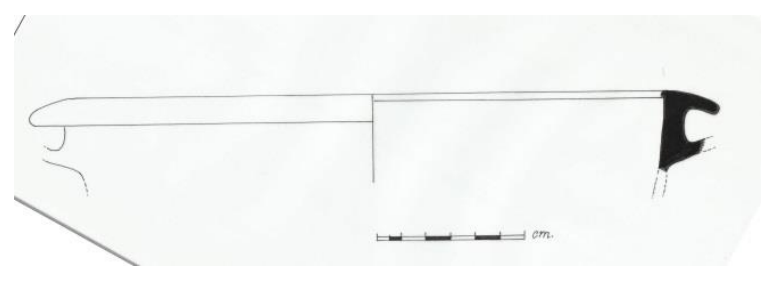
yatay kulpla birleşir.

Dönemi: MÖ I. yüzyıl ortası

Karşılaştırma: Hayes 1985, 87 Lev. 20, Kat. No. 13; Hayes 1991, 45;Uygun 2012, Kat. No. 653.

46 Hayes 1985, 84 Lev. XIX 12.

47 Rotroff 1997, 341 Res. 63, 996. 1004. Atina Agorası'nda ele geçen kaselerde ince sürülmüş, mat görünümlü kırmızı astar bulunur.

48 Hayes 1985, 22-23 Form 20 Lev. III 8. DSA örnekleri MÖ II. yüzyılın ikinci yarısına tarihlenir.

49 Uygun 2011, Kat. No. 621.

50 Hayes 1985, 80; Kenrick 1985, 267; Sackett 1992, 152.

51 Hayes 1985, 87 Lev. XX 13; Hayes 1991, 45.

52 Uygun 2011, Kat. No. 653. 
Krater Form 2-Hayes Paphos $37^{53}$ (Kat. No. K. 14-16, Fig. 2): Hafif dışa taşkın ağız; derin bir yivle iki parçaya ayrılan yatay dudak; uzun boyun, keskin profille vurgulanan yuvarlak gövdesi olan krater formudur. Andriake'den 3 örnek bu grupta değerlendirilmiş olup, bunlardan Kat. No. 18 no.lu örneğin iç bükey profilli boyun kısmı biraz daha kısa olup, diğerlerinden ayrılmaktadır. Benzer örnekler, Atina ${ }^{54}$, Antiokheia, Tarsus, Tel Anafa ${ }^{55}$, Samaria, Nessena, Nabatia Bölgesi ve Patara'dan ${ }^{56}$ ele geçmiştir. Benzer örnekler ışığında MÖ I. yüzyılın ikinci yarısı ile MS I. yüzyılın birinci yarısına tarihlemiştir.

Kat. No.: K. 14, Fig. 2.

Ölçüler: A. Ç.:14, $5 \mathrm{~cm}$ Y.:2,5 cm K.C..: Hamur Rengi: 2,5 YR 7/8 - light red Astar Rengi: 2,5 YR 5/6 - red Form: Dik ağız, dışa taşkın ve içbükey yivle kademelendirilen dudak, dik boyun ve keskin bir profille boyundan ayrilan

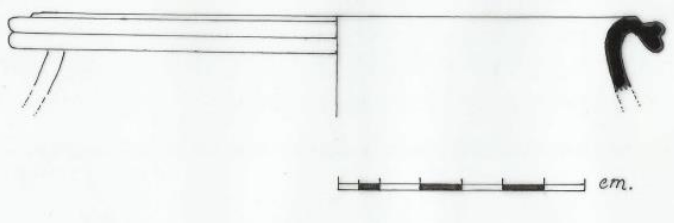
gövde.

Dönemi: MÖ I. yüzyılın ikinci yarısı ile MS I. yüzyııın birinci yarısı

Karşılaştırma: Hayes 1985, 87 Lev. XX 14; Hayes 2008, 202 Çiz. 26, 811-813;Uygun 2011, Kat. No. 644.

Kat. No.: K. 15, Fig. 2.

Ölçüler: A. Ç.: $22,5 \mathrm{~cm}$ Y.: $3 \mathrm{~cm}$ K.Ç.:

Hamur Rengi:5 YR 7/6 - reddish yellow.

Astar Rengi: 2,5 YR 6/6 - light red.

Form: Hafif dışa açılan ağız, dışa taşkın,

içbükey yivle kademelendirilen dudak,

uzun dik boyun, köşeli bir profille boyundan ayrılan ve üzeri yivlerle hareketlendirilen gövde.

Dönemi: MÖ I. yüzyılın ikinci yarısı ile MS I. yüzyılın birinci yarısı

Karşılaştırma: Hayes 1985, 87 Lev. XX 14; Hayes 2008, 202 Çiz. 26, 811-813; Uygun 2011, Kat. No. 647.

Kat. No.: K. 16, Fig. 2.

Ölçüler: A. Ç.: 13, $5 \mathrm{~cm}$ Y.: $2 \mathrm{~cm}$ K.Ç.:

Hamur Rengi: 2,5 YR 6/8 - light red

Astar Rengi: 2,5 YR 5/6 - red

Form: Dik ağız, dışa taşkın ve derin bir yivle

kademeli görünüm kazanan dudak, içbükey

profilli kısa boyun ve keskin bir profille boyundan ayrılan gövde.

Dönemi: MÖ I. yüzyılın ikinci yarısı ile MS I. yüzyılın birinci yarısı

Karşılaştırma: Hayes 1985, 87 Lev. XX 14; Hayes 2008, 202 Çiz. 26, 811-813;Uygun 2011, Kat. No. 652.

Krater Form 3- Hayes Paphos $40^{57}$ (Kat. No. K. 17, Fig. 2): DSD grubu içerisindeki en yaygın formlarından biridir bu kraterler. İçe dönük ağız; sivri ya da yuvarlak bitimli, içbükey yivle iki

53 Hayes 1985, 87 Lev. XX 14.

54 Hayes 2008, 202 Çiz. 26, 811-813.

55 Slane 1997, 377 Lev. 26 FW 583. 584.

56 Uygun 2011, Kat. No. 644-647.

57 Hayes 1985, 88 Lev. XXI 4-5. 
parçaya ayrılan dışa taşkın ve aşağı sarkık dudak; dik boyunlu ve kaideye doğru dar bir açıyla kapanan, dışbükey gövdeli krater formudur. Gövde üzerindeki rulet bezemesi bulunur. Benzer örnekler Hayes'e göre, Paphos, Soli, Kythera ve Ashdood'da ayrıca, Geniş bir yayılım alanı bulunan Kıbrıs kraterleri Tarsus ${ }^{58}$, Knossos ${ }^{59}$, Perge ${ }^{60}$, Kyaneai $^{61}$, Patara ${ }^{62}$, Berenice' de ${ }^{63}$ görülür. Hayes'in tarihlendirilmesine göre ${ }^{64}$ ve benzer örnekler ışığında MS I. yüzyılın sonuna tarihlenmektedir.

Kat. No.: K. 17, Fig. 2.

Ölçüler: A. Ç.: 33, $5 \mathrm{~cm}$ Y.: 5, $5 \mathrm{~cm} \mathrm{K.Ç.:.}$

Hamur Rengi: 5 YR 7/8 - reddish yellow.

Astar Rengi: 5 YR 6/8 - reddish yellow.

Form: İçe kapanan ağız, sivri uçla sonlanan,

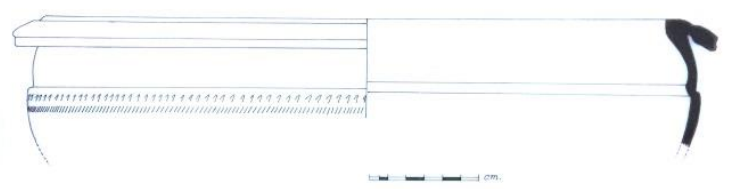

dışa taşkın, aşağıya sarkık ve derin bir yivle ikiye ayrılan üçgen kesitli dudak ve kaideye doğru daralan dışbükey gövde profili görülür. Gövde üzerinde iki sıra çizgisel rulet bezemesi bulunur.

Dönemi: MS I. yüzyıl

Karşılaştırma: Hayes 1985, 88 Lev. XXI 4-5; Yılmaz 2008, 109 Lev. LXIII 20; Lund 1997, Lev. 1, Form X 38; Uygun 2011, Kat. No. 640.

Krater Form 4 -Hayes Form X 38 (Kat. No. K. 18-19, Fig. 2): Andriake'den ele geçen makara kaideli kraterin tabanı ele geçmiştir. Bu krater formunun korunmuş örneklerinin genel form özelliği dışa açılan ağız, dikey profilli dudak, uzun boyunlu yuvarlak formlu gövdesi olmasıdır. Kraterin tabanında makara formlu üç adet ayak bulunur. Bu ayaklar sayesinde krater ayakta durmaktadır. Gövde üzerinde bant halinde rulet vs. gibi bezemeler bulunur. Andriake'den iki farklı kratere ait astragal formunda makara formlu kaide örneği ele geçmiştir. Benzer örnekler Paphos $^{65}$, Atina Agorası'ndan ${ }^{66}$ ele geçmiştir. Bu örnekler ışığında, MS I. yüzyıl sonuna tarihlenmiştir.

Kat. No.: K. 18, Fig. 2.

Ölçüler: A. Ç.: $\mathrm{cm}$ Y.: $2.3 \mathrm{~cm}$ K.Ç.:

Hamur Rengi: 2, 5 YR 6/6 light red.

Astar Rengi: 2,5 YR 5/8 - red

Form: Makara formlu 3 ayaktan oluşan tabana sahip krater formu. Tabana doğru stilize palmet yaprağı bezeği bulunur.

Dönemi: MS I. yüzyılın sonu.

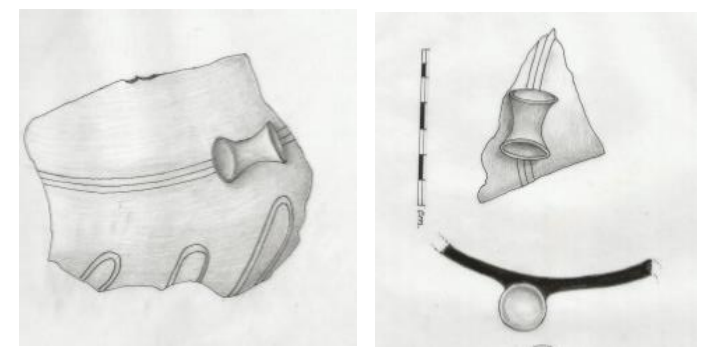

Karşılaştırma: Lund 1997, Lev. 1, Form X 38; Kenyon 1957, Fig. 69, Kat. No. 1; Hayes 1985, Lev. $X X I$, Kat. No. 2.

\footnotetext{
Jones 1950, 272 Res. 203, 773.

Sackett 1992, 251 Lev. 192, 30 a,b.

Firat 1999, 25.

Yılmaz 2008, 109 Lev. LXIII 20.

Uygun 2011, Kat. No. 640.

Kenrick 1985, 270 Res. 49, 385. 1-3.

Hayes 1991, 45.

Hayes 1985, 88, Lev. XXI, X Form 38.

66 Hayes 2008, Fig. 26, Kat. No. 813 (P 11544).
} 
Kat. No.: K. 19, Fig. 2.

Ölçüler: A. Ç.: $-Y .: 3 \mathrm{~cm}$ K.Ç.:

Hamur Rengi: 2, 5 YR 6/6 light red.

Astar Rengi: 2,5 YR 5/8 - red.

Form: Makara formlu 3 ayaktan oluşan tabana sahip krater formu. Tabana

doğru rulet bezeği bulunur.

Dönemi: MS I. yüzyılın sonu.

Karşılaştırma: Lund 1997, Lev. 1, Form X 38; Slane 1997, Lev. 36, FW 589;

Hayes 1985, Lev. XXI, Kat. No. 2.

DSD Grubu Testi

Emzikli Testicik Form 1 (Kat. No. T. 20-22, Fig. 3): Andriake'den bu formdaki testiye ait üç farklı parça ele geçmiştir. Bunlardan ilki, testinin İçe kapanan huni formlu daralarak, gövde ile birleşen bölümüdür. Testinin bu bölümünde, kulp bulunmaktadır. Andriake'den gövdeye ait 2 farklı parça ele geçmiştir. T. 21 no. lu örneğin gövdesi daha keskin bikonik formda olup yivler bulunur, ince uzun bir emzik kısmı vardır. T. 22 no. lu örneğin gövdesi ise, daha yumuşak profilli olup, üzerinde çizgisel yivler vardır, emzik kısmının olduğu bölüm kırık olarak ele geçmiştir. Testi kaideye doğru daralan torba formundadır. Kaidesi geniş ve alçaktır. Bu testi formu günümüz çaydanlığına benzemektedir. Bu forma ait örnekler nadir bulunmakta olup, benzer örnek Pergamon ${ }^{67}$, Paphos'tan ele geçmiştir ${ }^{68}$. Bu örnek ışığında Andriake örneği, MS I. yüzyıla tarihlenir.

Kat. No.: T. 20, Fig. 3.

Ölçüler: A. Ç.: 8,5 cm Y.: $3 \mathrm{~cm} \mathrm{K.Ç.:.}$

Hamur Rengi: 2, 5 YR 4/4 reddish brown.

Astar Rengi: 2,5 YR 4/8 - red.

Form: Testinin içe kapanan huni formunda bir profili bulunur.

Dudağın üzerinde ince çizgisel profiller bulunur. Tek tarafta

kulbu bulunur.

Dönemi: MS I. yüzyıl.

Karşılaştırma: Hayes 1991, 189 Lev. LXVI, Res. 36; Hayes 1985, Lev. 21, Kat. No. 8.

Kat. No.: T. 21, Fig. 3.

Ölçüler: A. Ç.: cm Y.: $9 \mathrm{~cm}$ K.Ç.:

Hamur Rengi: 2, 5 YR 4/4 reddish brown.

Astar Rengi: 2,5 YR 5/6 - red

Form: İçe kapanan huni formlu dudak formu daralarak, gövde ile birleşir. Gövde bikonik formda ve bir ibrik bölümü bulunur.

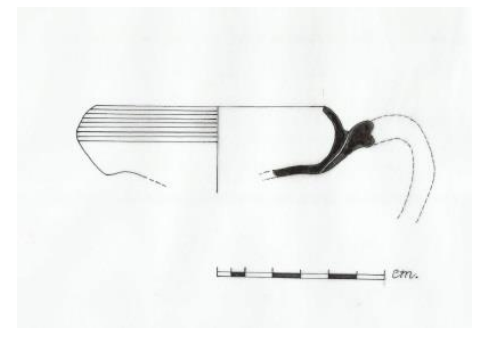

Dönemi: MS I. Yüzyıl.

Karşılaştırma: Hayes 1991, 189 Lev. LXVI, Res. 36;
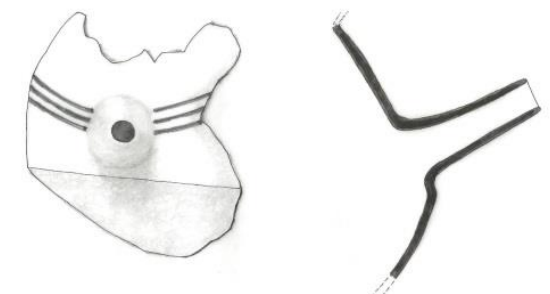

Hayes 1985, Lev. 21, Kat. No. 8.

67 Meyer-Schlichtmann 1988, Lev. 39, Kr. 7a.

68 Age. 1985, 89, Lev. XXI, Kat. No. 8; Hayes 1991, 189 Lev. LXVI. 
Kat. No.: T. 22, Fig. 3.

Ölçüler: A. Ç.: cm Y.: 7,5 cm K.Ç.:

Hamur Rengi: 7, 5 YR 8/6 reddish yellow

Astar Rengi: 2,5 YR 5/8 - red

Form: İbrikli hafif küresel formlu testinin üzerinde çizgisel yivler

bulunmaktadır. İbrik bölümünden kırılmıştır.

Dönemi: MÖ I. yüzyıl sonu - MS I. yüzyıl.

Karşılaştırma: Rotroff 1997, 357 Lev. 73, Res. 1191.

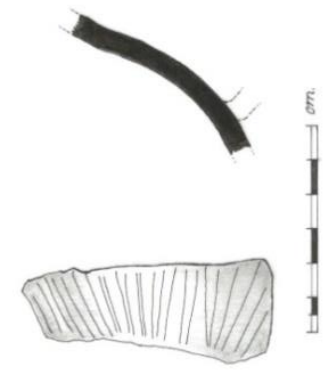

And. DSD Sigillata Bezemeleri:

Rulet Bezemesi: T. 1 no.lu tabağın geniş, düz dudağı üzerinde 3

sıra rulet bezemesi görülmektedir (Fig. 1). Birebir benzer bezemesi bulunmasa da Patara'da DSD grubundan Kat. No. 635 no.lu örnek ile Sagalassos Grubundan Kat. No. 683 no.lu örnekle benzeşmektedir ${ }^{69}$.

K. 17 no.lu DSD grubuna ait kraterin dirsek kısmında rulet bezemesi bulunur (Fig.2). Benzeri Patara'dan Kat. No. 547 no.lu örnektir ${ }^{70}$. K. 26 no.lu DSD grubuna ait kraterin üzerinde rulet bezemesi bulunur (Fig. 2). Benzeri Patara'dan Kat. No. 540 no. lu örnektir ${ }^{71}$.

Çizgisel Bezeme: K. 25 no. lu DSD grubuna ait makaralı kraterin üzerinde stilize taç yaprağının uç kısımlarına benzeyen çizgisel bulunur (Fig. 4). Benzer bezemeler Pontus sigillatalarında bulunur ${ }^{72}$

\section{Değerlendirme ve Sonuç}

\section{Andriake Limanının Lykia Deniz Ticareti Açısından Önemi ve Değerlendirilmesi:}

Lykia Bölgesi'nin içerisinde bulunduğu deniz rotalarından biri Doğu Akdeniz ticaret rotasıdır. Mısır'dan başlayarak, Levant, Anadolu'nun güney kıyıları, Girit, Yunanistan ve Roma'ya kadar devam eder. Lykia Bölgesi; Kıbrıs ile Rhodos deniz rotasında, kısa mesafeli kıyı seyiri yapan denizciler açısından lojistik intiyaçların karşılanabileceği önemli bir ikmal ve malların takasının yapıldığı, ticaret bölgesidir ${ }^{73}$. Lykia hareketli kıyı şeridi ile önemli uğrak ve barınak noktaları olan, irili ufaklı çok sayıda limana sahip olması deniz ticareti açısından bölgenin önemini arttırmakta$\mathrm{dır}^{74}$. Stadiasmus Maris Magni'de, MÖ IV. yüzyıl'da Pseudo-Skylaks'tan alınan bilgilerle, anlatılan deniz rotaları şöyledir ${ }^{75}$. Lykia'da doğudan batıya limanlar sırasıyla Idyros, Phaselis, Korykos, Olympos, Posidarisus, Melanippe, Gagai, Phoinikos olup, bu limanlar Batı Lykia Bölgesi'ndedir. Orta Lykia Bölgesi'de Andriake, Simena, Teimiusa, Aperlai, Antiphellos, Kalamaki, Phoinike'dir. Batı Lykia Bölgesi'nde Patara, Pydnai, Artymnessos/Perdikia, Kalabantia, Karmylessos, Telmessos, Krya, Lissa ve Lydai'dır. Bu limanlardan birkaç tanesi büyük limanlar olup, çoğunluğu küçük limanlardır. Orta Lykia'da batı rüzgârlarının hâkim olduğu, kayalıklı ve Gelidonya burnundan Patara'ya kadar olan kısımda, korunaklı olan Andriake limanın önemi büyüktür.

Strabon, kayalık Lykia'nın engebeli topografyasında, çok sayıda korunaklı limanın olduğundan bahsetmektedir ${ }^{76}$. Plinius'un Andria civitas ${ }^{77}$ olarak bahsettiği Andriake liman yerleşimi, Orta

\footnotetext{
69 Uygun 2011, 148.

70 Age. 2011, 148.

Age. 2011, 148.

72 Hayes 1985, Lev. XXIII, 10-11.

73 Özdilek 2017, 353.

74 Age. 2017, 354.

75 Aslan 2010, 258.

76 Strabon XIV, III, 2.
} 
Lykia Bölgesi'nin Klasik Çağdan ${ }^{78}$, MS VII. yüzyıl sonuna kadar faal durumda işleyen büyük kapasiteli, kıtalar arası mesafede yapılan, deniz ticaret rotasında önemli bir limanıdır. Andriake yerleşimi, sadece liman işlevindeki yapılara sahip olup Myra'ya bağlıdır. Andriake liman yerleşimi olması açısından Roma İmparatorluğu için Batı Anadolu kıyılarının kontrolü, zenginliklerinin Roma’ya aktarıldığı ve Doğu'dan gelen malların bu limana taşındığı ticari bir merkezdir. Ayrıca Andriake limanına gelen ithal ürünler bu liman aralığıyla iç pazara dağılmakta, Lykia'da üretilen yerel ürünler; myrex'ten üretilen mor boya, sedir ağacı, zeytinyağı, şarap, buğday, parfüm, ilaç, krem, sünger, garrum, Patara Sandaletleri, tuzlanmış balık etc. ${ }^{79}$ ).

Roma Imparatorlarından Germanicus ve karısı Agrippina'nın Andriake-Myra'ya ziyaretinin ardından, Myra halkının Roma imparatorlarına bağılıklarını göstermek amacıyla, Andriake limanında Augustus, Tiberius, Germanicus, Agrippina, Agrippa, Drusus, Julia Augusta, Gaius Caesar'ı heykellerini dikerek onurlandırdıkları bir anıt bulunmaktadır ${ }^{80}$. Nero adına da Andriake'de bir onurlandırma yazıtı bulunmaktadır. Nero Dönemi'ndeki Roma için kentin önemini gösteren diğer bir veri, gümrük yazıtıdır ${ }^{81}$. Gümrük yazııının yerleşimdeki varlığı, Lykia Birliği için, işlek ticaretin yapıldığı bir liman olduğunu göstermesi açısından son derece önemlidir. Kentteki en görkemli yapı yerleşimin güney merkezinde yer alan, Imparator Hadrian'a adanan granariumdur. Bu yapıda, İskenderiye'den getirilen buğday depolanır, ayrıca Lykia Bölgesi'nde yetişen hububat toplanarak Roma'ya taşınır. Lykia Bölgesi'nde bulunan diğer bir granarium Patara'da bulunmakta olup, bölgenin en büyük iki limanında yer alan granarium yapıları Roma'nın bu yerleşimlere verdiği önemi göstermektedir. Yine Hadrian Dönemi'ne tarihlenen plakoma-agora'da ticaret yapılmaktadır.

Limanlar farklı halkların ve kültürlerin temsilcilerinin karşılaştığı ve malların değiş tokuşunun yapıldığı yerler olup, farklı bölgelerin kültür değişimlerinin odak noktası olduğu gösteren ${ }^{82}$ Andriake örneği de bu bağlamda kültürel önem taşımaktadır. Andriake limanın özellikle Doğu Akdeniz'le yoğun ticari ilişkileri olduğu arkeolojik veriler ile yazıtlar yoluyla ortaya çıkarılmıştır. Mısır'ın baş tanrıları olan İsis ve Serapis'in kentte hem granarium hem de liman dükkânlarında kabartmalarının olması da ticari ilişkilerle birlikte kültürel, dinsel etkileşiminde kentteki varlığını göstermektedir.

\section{Andriake'de Sinagog Yapısının Değerlendirilmesi}

Andriake'de ortaya çıkarılan, Lykia Bölgesi'nin ilk sinagog yapısı, Granarium'un kuzeyinde bulunan rıhtım caddesine bakmaktadır. Limandan gelenlerin rahatlıkla görebileceği, en merkezi alanlardan birine inşa edilmiştir. Andriake'de çok sayıda kilisenin varlığı, MS V. yüzyılda Hac yolculuğunda, Myra'ya başta Saint Nikalaos gibi azizlerin martyrionlarını ziyaret etmeye gelen hacılar tarafından kullanılmasıdır. Hristiyanlık dini açısından son derece önemli bir merkez olan Myra ve limanı Andriake'de bu denli kilisenin işler olduğu MS V. yüzyılda, limanın en anıtsal yapısı granariumun batı köşesine sinagogun inşa edilmiş olması, farklı dinsel inançlara sahip, özgürlükçü ve kozmopolit bir yapıda olduğunu göstermesi açısından oldukça önemlidir. Lykia'da

77 Plinius NH,5, XXVIII.

78 Kazılar öncesi çalışmalardan ve antik kaynaklarda Skylas'ta kentin Klasik Dönemi'ne ilişkin verilerinin olmaması üzerine yerleşimin tarihi Hellenistik Dönem'den başlatılmışıı. Onurlandırma Anıtı ve Sinagog Apsis alanı kazılarından Klasik Döneme ait seramikler ile Sinagog Apsis'in Klasik Döneme'e ait Aspendos sikkesinin ele geçmesi yerleşimin tarihini şimdilik Klasik Dönem'e çekmiştir.

79 Aslan 2010, 260.

80 Çevik-Bulut 2010, 27.

81 Takmer 2007, 170.

82 Aslan 2010, 257. 
ticaretin yoğun olarak yapıldığı bu liman yerleşiminde erken Yahudi cemaatinin varlığı ve tarihsel süreçte Yahudilerin ticaretle ilgilenmiş olmaları ile örtüşmektedir. Küçük boyutlu sinagogun limanın en merkezi yerindeki varlığı, ticaret yapmaya gelen ve yerleşimde yaşayan az sayıdaki cemaate de hizmet vermeye yönelik olarak inşa edilmiş olabileceğini göstermektedir. Dolayısıyla kentte yaşan insanların dini anlamda çeşitli inançlara sahip olduğu, kozmopolit bir yapısı olduğu düşünülmektedir. MS V.-VI. yüzyıla tarihlenen sinagogun zemin seviyesinin altındaki apsis alanından ele geçen seramiklerin değerlendirmeleri sonucunda ${ }^{83}$ malzemenin homojen olmadığı, kentteki seramik çöplüğünden getirilerek, ana kaya arasında kalan boşlukları doldurmak amacıyla tesviye yapıldığı anlaşılmıştır. Alandan ele geçen Hellenistik ve Roma dönemi seramikleri çalışılıı̧tır. Terra sigillatalar ise bu alanda en çok yoğunluk gösteren seramik grubudur. Tüm terrasigillatalardan 193 parça çalışılmış olup, bu alandan ele geçen en yoğun grup, tüm sigillataların \%60'ını oluşturan DSA grubu seramikleridir. Sigillatalar içerisinde en erken ortaya çıkan DSA grubundan sonra Kıbrıs Sigillata üretimi gelmektedir. Bu alandan ele geçen seramiklerin \%22'sini Kıbrıs sigillataları oluşturmaktadır (Grafik 1). Lykia Bölgesi'ndeki önemli bir liman olan Andriake seramiklerinin çalışılmasıyla özellikle Hellenistik Dönemde Batı Anadolu özellikle Knidos, Ephessos ve Bergama'dan seramik ithal edildiği görülmüştür. Erken Roma Dönemi'nde ise, Tarsus, Antiokheia, Kuzey Suriye'den Tel Anafa, Samaria, Hama kentlerinden seramiklerin ithal edilmiş olduğu görülmüştür. MÖ I. yüzyılın ikinci yarısında Kıbrıs seramiklerinin ticareti artmış özellikle Anadolu'da Kilikia ${ }^{84}$, Pamphilya ${ }^{85}$, Lykia Bölgesi'ndeki en yoğun olarak Patara ${ }^{86}$, ardından Andriake ${ }^{87}$, Letoon ${ }^{88}$, Xanthos ${ }^{89}$ ve Limyra ${ }^{90}$ kentlerinden DSD seramikleri ele geçmiştir. Lykia Bölgesi liman kentlerinden Patara ile Andriake'den ele geçen sigillataların yoğunlukları ve ele geçen kap formları bakımından benzerlikler bulunur ${ }^{91}$. Bu da bize, Roma Dönemi moda olan farklı formdaki masa kapları olan sigillataların, Lykia'da da rağbet gördüğünü, bölgenin dönem modasına uyduğunu göstermektedir.

DSD formları içerisinde formsal çeşitlilik ve yoğunluğun kraterlede olduğu görülmüştür. Kraterler üzerinde rulet, palmet baskılarına rastlanmaktadır. Sigillatalar içerisinde, servis amaçı kullanılan kraterlerin, en zengin olduğu grup, Kıbrıs seramikleridir. Patara'da krater formları zengin olmasına karşın Andriake'den Patara'dan farklı olan makara kaideli kraterler bulunur. ibrik-emzikli testiler, palmet bezemeli fincan ile şişe örnekleri, Kıbrıs sigillataları içerisinde Paphos dışında ender rastlanılan formlar olup, bu örnekler Lykia Bölgesi'nde şimdiye kadar sadece Andriake'den ele geçmiştir.

DSD grubu seramiklerinin üretim merkezleri ile farklı görüşler olsa da, kil analizlerinde Kıbrıs'ta üretimin olduğu kanıtlanmıştır. Andriake'den ele geçen DSD grubunda değerlendirilen örnekler form ve Kıbrıs'tan ele geçen, özellikle Paphos örneklerinin hamur-astarlarının karşılaştırılması sonucunda bu grupta değerlendirilmiş olup, Andriake'de kil analizi yapılmamıştır.

83 Özdilek 2015; Özdilek 2016.

84 Kıbrıs sigillatalarının dağılımı bkz. Lund 1997, 201-211.

85 Oransay 2012, 109-138.

86 Uygun 2008, 305-322.

87 Yener-Marksteiner 2013, 15-20.

88 Courtils - Laroche 2004, 309-340.

89 Pellegrino 2002, 45-260.

90 Yener-Marksteiner 2012, 371-386; Rückert 2003, 60-61.

91 Patara'dan ele geçen DSD seramiklerinin sayısal yoğunlukları için bkz. Uygun 2011, 166, Grafik 1; DSD seramiklerinin kap türlerine göre sayısal dağılımı için bkz. Uygun 2011, 168, Grafik 7. Patara'daki DSD seramiklerinin tipolojileri için bkz. Uygun 2011, 158 Tablo 20. 
Munsell kataloğuna göre ele geçen örneklerde 3 grup hamur yapısı gözlemlenmiştir.

1- 2,5 YR 5/8, 6/4, 6/6, 6/8, 7/6, 7/8; $10 R$ 4/8, 5/6 açık kırmızı ya da kırmızı hamur. 18 adet seramikten oluşan bu grup toplam DSD örneklerinin oluşturur.

2- 5 YR 5/6, 6/4, 7/4, 7/6, 7/8 kırmızımsı sarı, pembemsi tonların görüldüğü 7örnek toplam DSD seramiğidir.

3- 7,5 YR 6/3 açık kahverengi hamur. Yalnızca 4 parçayla örneklenen bu hamur rengi toplam DSD seramiğidir.

Sert pişimli, genellikle kırmızı tonlarındaki hamur içerisinde kireç ve diğer katkı maddeleri yoğun olduğu için hamur tanecikli dokuya sahiptir. Genelde mat kahverengimsi ve morumsu kırmızı tonlarındaki astar (2,5 YR 4/4, 4/3, 4/6, 4/8, 5/6, 5/8, 6/8; $10 \mathrm{R} \mathrm{4/4,4/6,5/6,5/8),} \mathrm{bazı}$ örneklerde ise parlak bir yapıdadır. Andriake'den ele geçen DSD grubu örneklerinin Hayes'in Paphos seramiklerinin hamur-astar tanımlaması doğrultusunda Kıbrıs Adası üretimi olmalıdır.

Andriake'den ele geçen DSD grubu seramikleri baskı çeşitliliği konusunda zengindir. Bu grupta rulet baskıları, stilize farklı baskı çeşitliliği olan palmet yaprağı baskıları ile çizgisel bezemeler bulunmaktadır. Ele geçen örneklerdeki rulet bezemesi kendi içerisinde çeşitlilik göstermekte, doğu ve batı Sigillata gruplarına göre Kıbrıs sigillatalarında daha yaygın kullanılmıştır.

Bu çalışmada değerlendirilen DSD grubu seramiklerinin tarihleri MÖ I. yüzyıl başı ile MS II. yüzyıl arasına tarihlenmektedir. Genel kabul görüş, Kıbrıs seramiklerinin ticaretin en parlak olduğu dönem MÖ I. yüzyılın ikinci yarısıdır. Fakat Andriake'den ele geçen MÖ I. yüzyıl başına tarihlenen içe dönük ağızlı kâselerin varlığı tıpkı Patara'da da görüldüğü gibi ticaretin MÖ ı. yüzyıl başında olduğunu göstermesi ve ticaretin yapıldığı tarihi erkene çekmesi açısından kayda değerdir. Ayrıca Kıbrıs ile seramik ticareti-ithalatı MS III. yüzyıl ve sonrasında da devam etmiştir. Bu ticaretin varlığını, Sinagog'tan ele geçen ve Geç Roma Dönemi'ne tarihlenen, Kırmızı Astarlı Kıbrıs seramikleri göstermektedir. Kıbrıs'la ticaretin uzun süre devam ettiğini gösteren diğer veriler Bizans Dönemi'ne tarihlenen Myra'dan sırlı Enkomi tarzı Kıbrıs tabaklarıdır. Bu sırlı tabakların Myra'daki varlığı, MS XIII. yüzyıla kadar Kıbrıs ile ticari ilişkileri göstermektedir ${ }^{92}$. Andriake MS VI. yüzyıldan itibaren 529-530 ardından 601-602'de yaşanan depremler sonucunda liman seviyesi yaklaşık 2 m çökmüş, limanın etkin kullanımı bu doğal felaketlerden dolayı azalmış ardından 542-748 yılları arasında yaşanan veba salgınıyla yerleşimin nüfusunda düşüş yaşanmıştır $^{93}$. Arap savaşları MS 655 Phonikos-Finike Körfezi'nde yaşanmıştır ${ }^{94}$. Andriake limanı daha içte kalması ile izole bir durumdadır ${ }^{95}$. Kentteki sur sisteminin de tüm yerleşimi korumaya yönelik inşa edilmediği görülmektedir. MS IX-X. yüzyılda Tarsus'taki Müslüman donanmalar yaklaşık 250 yıl Andriake'deki ticareti engellemişlerdir ${ }^{96}$. MS 807 yılında ise, Humeyid İbn-i Mayuf güçleri saldıracakları Myra yerleşimi için Andriake limanı yerine Myra'ya daha yakın olan Taşdibi limanını kullanmışlardı९". Taş Dibi limanı Erken Roma'da küçük bir liman olup, özellikle Andriake limanının tsunamilerle ve alüvyal dolgularla dolması sebebiyle Orta Çă̆'da daha sık kullanılmış

Akyürek 2010, 159, Res. 12.

93 Duggan-Aygün 2010, 161.

Age. 2010, 161.

Age. 2010, 161.

96 Age. 2010, 161.

97 Age. 2010, 162. Humeyid İbn-i Mayuf, Abbasi Halifesi Harun El Reşid'in Suriye Valisidir. Kendisi önce Rhodos'a bir sefer düzenlemiş ardından da Myra'ya gelerek St. Nikolaos'un mezarı tahrip etmek istemişse de, başarılı olamamıştır. Bkz. Çevik 2015,46. 
olmalıdır ${ }^{98}$.

Kıbrıs adası aynı zamanda Roma Dönemi'nde Roma'nın Doğu eyaletleri içerisinde yer alarak Mısır'a bağlanmıştır ${ }^{99}$. Andriake limanının da özellikle Mısır'la ticari ilişkilerinin yoğun olduğu bu süreçte, İskenderiye'den tahıl yüklü gelen gemilerin Kıbrıs'a uğrayarak burada üretilen seramik, cam, aromatik yağ, zeytinyağı, şarap, kereste, bakır, haş haş alarak ${ }^{100}$ Akdeniz sahil şeridini takip ederek Andriake'ye ulaştığı düşünülmektedir. Kıbrıs'ta en erken seramikler üretimi Kalkolitik Dönem'de başlayarak ${ }^{101}$, Orta Çağ'a kadar kesinsitiz devam eder. Adanın seramik üretimine başladığı dönemden kısa bir süre sonra Bronz Çă̆ı'nda deniz ticaretinin başladığı (Gelidonya ve Uluburun batıkları ile MÖ XIV. yüzyıl - XII. yüzyı ${ }^{102}$ ) bilinmektedir. Lykia Bölgesi'nde, Kıbrıs'da üretilen, yayınlanan malzemelerden en erkeni ise, Patara'dan ele geçen MÖ VIII. yüzyıl sonuna tarihlenen "bichrome ve black on red" malzemedir ${ }^{103}$. Patara kazılarında da Klasik ve Hellenistik Döneme \%4'lük bir oranla Kıbrıs'a ait amphora ve az sayıda \%2'lik oranla Kıbrıs mühürlü amphoralarının ele geçmesi, bölgenin üretimi meşhur olan şarabı ve Hellenistik Dönem’le birlikte zeytinyağının, amphoralarla Lykia'ya ithal edildiğini göstermektedir ${ }^{104}$. Bunun yanı sıra yine Patara'dan MÖ I. yüzyıla ait ve Kıbrıs'ın meşhur üretimlerinden biri olan cam üreticiliğinden, amuletler ele geçmiştir ${ }^{105}$. Bütün bu arkeolojik veriler Kıbrıs adasının Lykia Bölgesi için özellikle Doğu'dan gelen ürünlerin ulaşmasında bir aracı olması ve böylece adada üretilen ürünlerinde bu kısa menzilli deniz ticaretinde alınarak başta Kilikia, ardından sırasıyla Pamphilya ve batı Akdeniz'de Lykia'ya ulaştığını göstermektedir. Lykia Bölgesi'nden de Rhodos, Ege Bölgesi-lonia, oradan da Yunanistan'a ulaşmış olmalıdırlar.

Lykia Bölgesi limanlarından kazısı yürütülen az sayıda liman yerleşiminden bir olan Andriake limanındaki seramiklerin çalışıması Lykia Bölgesi'ndeki diğer limanlarında ticaret ilişkilerine ışık tutar. Andriake'de ele geçen Kıbrıs seramiklerinin form çeşitliliği zengindir. Fakat alandan ele geçen her kaptan neredeyse 1 örnek bulunmaktadır. Bu çalışmada, sadece sinagog apsis alanından ele geçen terra sigillataların incelenmesi, bize Kıbrıs-DSD grubu seramiklerinin kentteki \%12'lik oranla, sayısal dağılımı hakkında sınırlı bilgi vermektedir. Fakat diğer bir yandan, incelenen seramikler, kentin seramik atık alanından getirilen karışık ve çok çeşitli seramiklerden meydana gelmiş olması, yaklaşık 1000 sene boyunca kentte kullanımda olan seramiklerin tipolojisi hakkında bir kesit sunmaktadır.

Kıbrıs adasının Lykia Bölgesi için önemi, doğuda üretilen ürünlerin aktarıldığı ticari bir merkez olmasıdır. Myra ve limanı Andriake'nin, Kıbrıs adası ile arasındaki ticari, dinsel ve kültürel ilişkiler, şimdiye kadar kazılardan ele geçen veriler ışığında, MÖ I. yüzyılın başından itibaren, MS XIII. yüzyıla kadar yaklaşık 1400 yıl boyunca, kesintisiz olarak sürdüğü arkeolojik verilerle ortaya konmuştur.

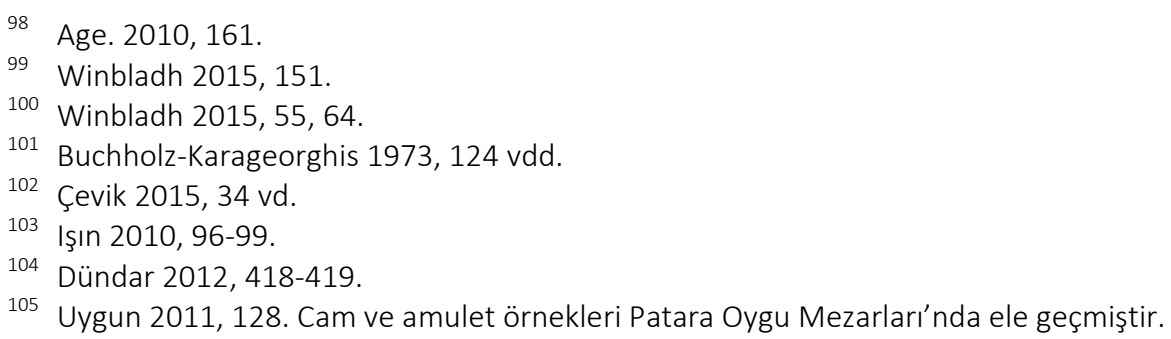




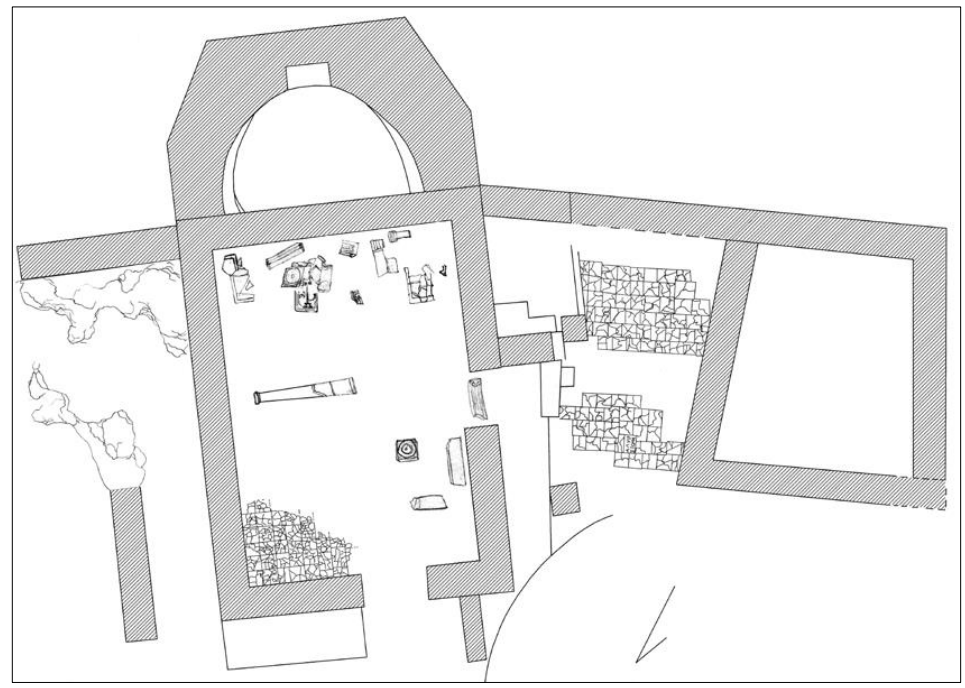

Fig. 4. Andriake Sinagog Planı

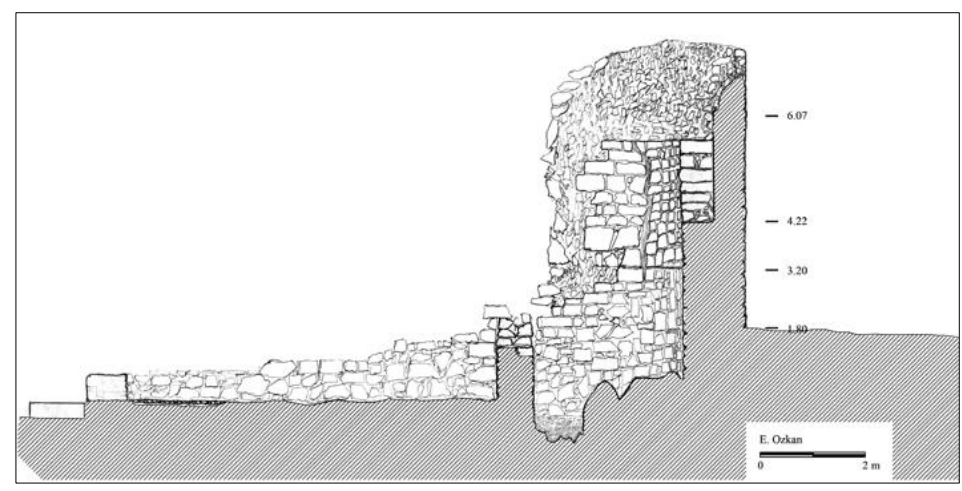

Fig. 5. Andriake Sinagog Kesiti

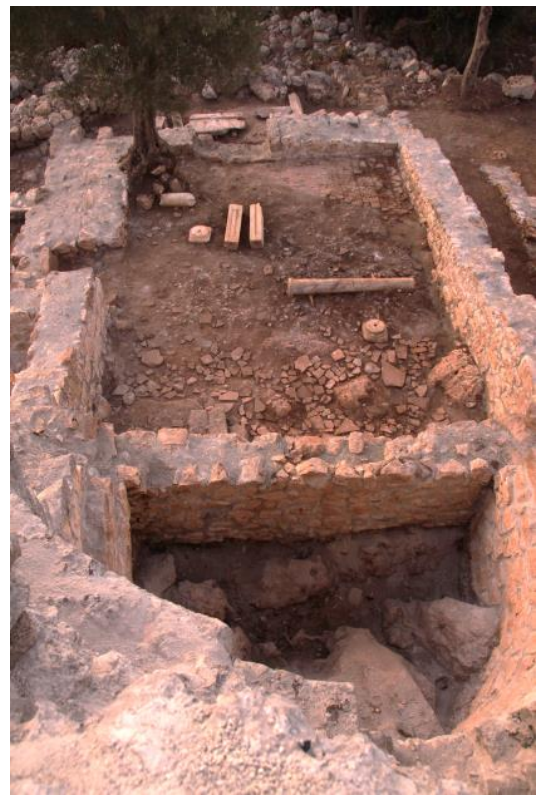

Fig. 6a. Andriake Sinagogu

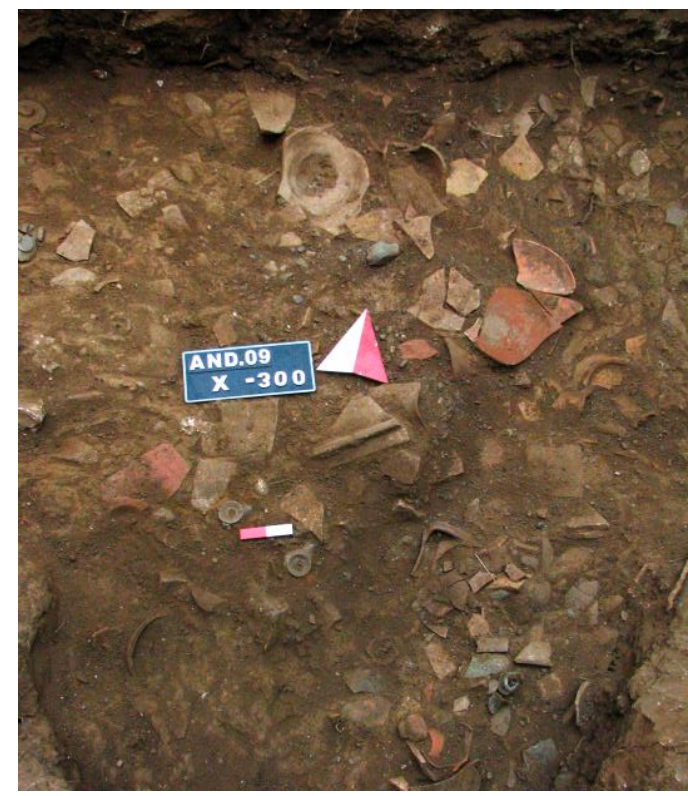

Fig. 6b. Andriake Sinagog Apsisi 
Tablo 1. Andriake DSD Tabak Tipolojisi

\begin{tabular}{|c|c|c|}
\hline Tabak & DSD Grubu & Tarih \\
\hline T.1 & & MÖ I. yüzyılın sonu. \\
\hline T.2 & & MÖ. I. yüzyılın ikinci yarısı. \\
\hline T. 2 & & MÖ. I. yüzyılın sonu - MS. I. yüzyılın birinci yarısı. \\
\hline T. 2 & & MÖ. I. yüzyılın sonu - MS. I. yüzyılın birinci yarısı. \\
\hline T. 2 & & MÖ. I.. yüzyılın sonu - MS. I. yüzyılın birinci yarısı. \\
\hline T. 3 & & MS. I. yüzyılın ikinci yarısı. \\
\hline T. 7 & & MS. I. yüzyılın ikinci yarısı. \\
\hline
\end{tabular}

Tablo 2. Andriake DSD Kase Tipolojisi

\begin{tabular}{|c|c|c|}
\hline Kase & DSD Grubu & \multicolumn{1}{|c|}{ Tarih } \\
\hline K.1 & MÖ I. yüzyıl sonu ile MS I. yüzyılın birinci yarısı. \\
\hline K.2 & & MÖ I. yüzyıl başı. \\
\hline
\end{tabular}

Tablo 3. Andriake DSD Testi-Şişe Tipolojisi

\begin{tabular}{|c|c|c|}
\hline Testi-Şişe Formu & DSD Grubu & Tarih \\
\hline T.1 & MS І. yüzyıl \\
\hline T.1 & MS I. yüzyıl \\
\hline T.1 & MÖ I. yüzyıl sonu - MS I. yüzyılın birinci yarısı \\
\hline
\end{tabular}


Tablo 4. Andriake DSD Krater Tipolojisi

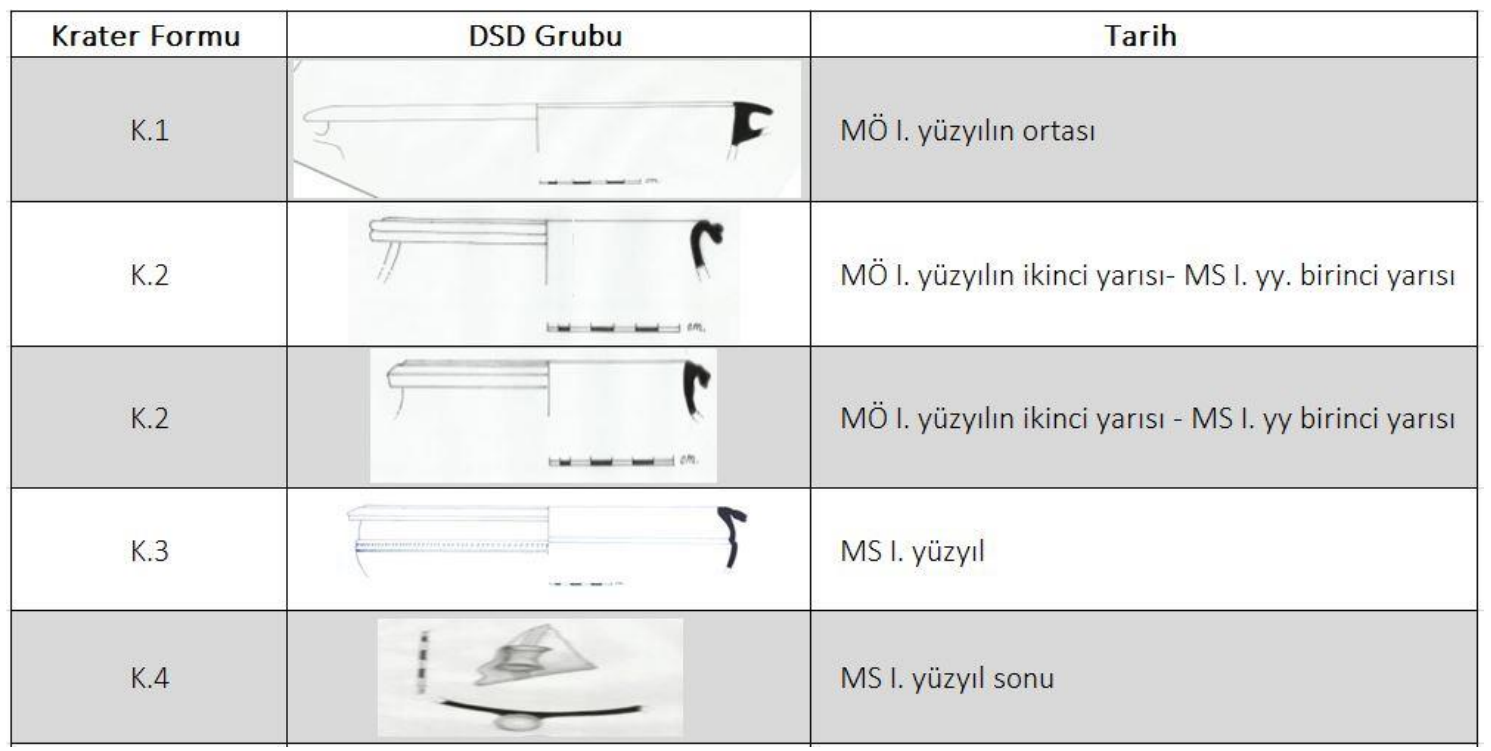

Grafik 1. Andriake'deki DSD Grubunun Kap Türlerine Göre Sayısal Dağılımı

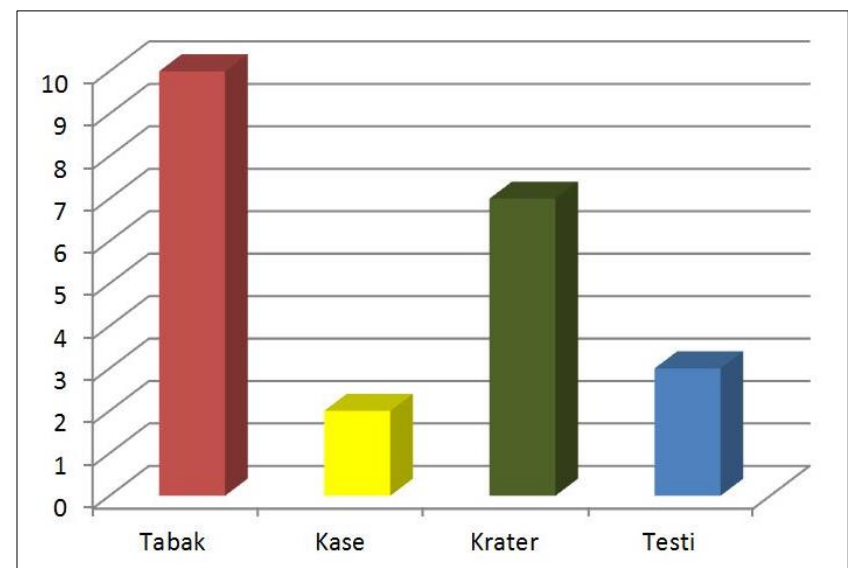

Grafik 2. Andriake'deki Terra Sigillatalarının Sayısal Dağılımı

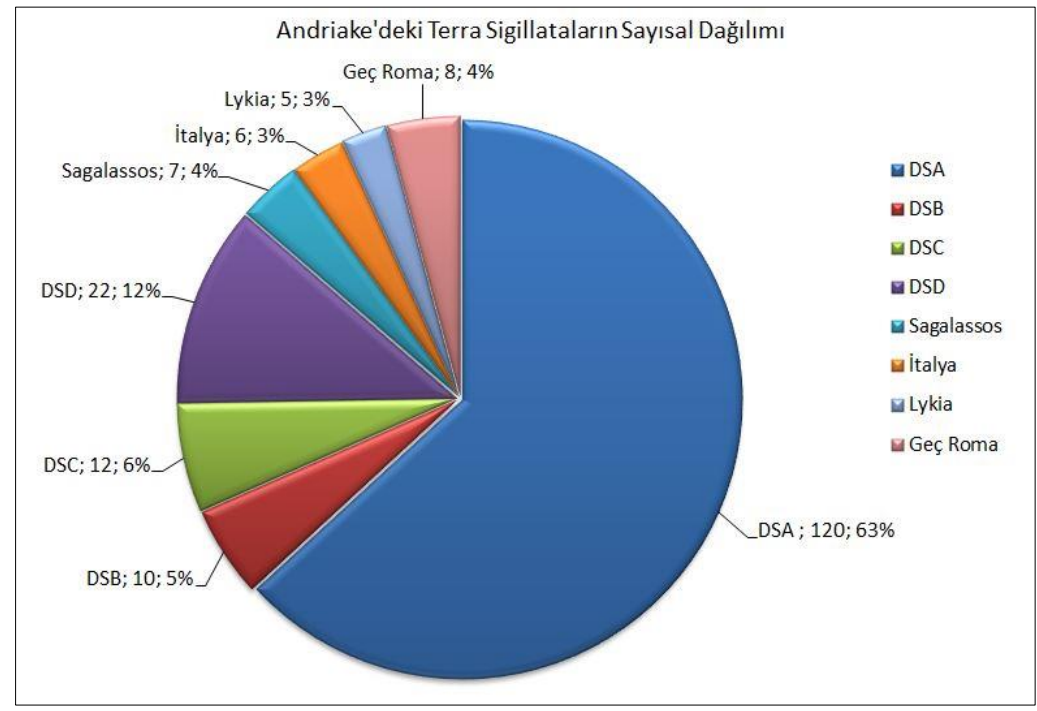




\section{BIBBLIYOGRAFYA}

\section{Antik Kaynaklar}

Plinius Nh.

Strabon

Modern Kaynaklar

Akyürek 2010

Adamsheck 1979

Aslan 2010

Buchholz - Karageorghis 1973 H. (1973).

Courtils - Laroche 2004

Çevik 2015

Çevik-Bulut 2010

Çevik et. al. 2010a

Çevik et al. 2010b

Çevik et al. 2010c

Duggan - Aygün 2010

Dündar 2012

Firat 1999

Fulford - Timby 1994

Gunneweg et al. 1983

Hayes 1967

Hayes 1971

Hayes 1972

Hayes 1973

Hayes 1983

Hayes 1985

Hayes 1991 (1855). 272. 51. 366.
Plinius, The Natural History. Pliny the Elder. John Bostock (Ed.), London

Strabon, Antik Anadolu Coğrafyası (Geographika XII-XIII-XIV) (Çev. A. Pekman) İstanbul (1993).

E. Akyürek, "Myra Şapeli Üzerine Ilk Notlar". Eds. N. Çevik, Arkeolojisinden Doğasına Myra-Demre ve Çevresi, Antalya (2010) 153-168.

B. Adamsheck, The Pottery, Kenchreai IV, Leiden 1979.

E. Aslan, "Myra Çevresinde Antik Denizcilik ve Sualtı Kültür Kalıntıları" Eds. N. Çevik, Arkeolojisinden Doğasına Myra-Demre ve Çevresi, Antalya (2010) 257-

J. Des Courtils - D. Laroche "Xanthos et le Letoon: Rapport sur la Campagne de 2003". Anatolia Antiqua XII, 2004, 309-340.

N. Çevik, Lykia Kitabı. İstanbul 2015.

N. Çevik - S. Bulut, "ikinci Kazı Sezonunda Myra ve Limanı Andriake". Eds. N. Çevik, Arkeolojisinden Doğasına Myra-Demre ve Çevresi, Antalya (2010) 25-

N. Çevik, S. Bulut, O. Tıbıkoğlu, B. Özdilek - A. Aygün "Myra-Andriake Kazılarında Ilk Yıl / The First Season of Excavations in Myra and Andriake: 2009". ANMED 8 (2010) 55 - 62.

N. Çevik, S. Bulut, O. Tıbıkoğlu - B. Özdilek "Myra ve Andriake Kazılarında Illk YIl: 2009". KST XXXII (2010) 403 - 420.

N. Çevik, Ö. Çömezoğlu, H. S. Öztürk - İ. Türkoğlu, "Unique Discovery in Lycia: The Ancient Synagogue at Andriake, Port of Myra". Adalya XIII (2010) 335-

M. Duggan - A. Aygün, "Myra'nın Ortaçağ ve Sonrasındaki Limanı "TaşdibiStamira" Eds. N. Çevik, Arkeolojisinden Doğasına Myra- Demre ve Çevresi, Antalya (2010) 161-168.

E. Dündar, Patara Kazılarından Ele Geçen (1989-2010 Yılları) Arkaik, Klasik ve Hellenistik Dönem Ticari Amphoralar ve Amphora Mühürleri. Yayımlanmamış Doktora Tezi, Akdeniz Üniversitesi. Antalya 2012.

N. Fırat, Perge Konut Alanı Keramiği. Yayımlanmamış Doktora Tezi, İstanbul Üniversitesi. İstanbul 1999.

M. Fulford - J. Timby, "The Fine Wares" Eds. M. G. Fulford - D. P. S.

Peacock, Excavations at Carthage the British Mission Volume II, 2 The Circular Harbour, North Side The Pottery, (1994) 1-21.

J. Gunneweg, I. Perlman - J. Yellin, The Provenience, Typology and Chronology of Eastern Terra Sigillata. Jerusalem 1983.

J. W. Hayes, "Cypriot Sigillata". RDAC (1967) 65-77.

J. W. Hayes, "Four Early Roman Groups From Knossos". The Annual of the British School at Athens 66 (1971) 249-274.

J. W. Hayes, Late Roman Pottery. Cambridge 1972.

J. W. Hayes, "Roman Pottery from the South Stoa and Corinth". Hesperia 42 (1973) 416-470.

J. W. Hayes, "The Villa Dionysos Excavations, Knossos: The Pottery". BSA 78 (1983) 97-169.

J. W. Hayes, "Sigillate Orientali". EAA. Atlante de le Forme Ceramiche II. Ceramics Fine Romana Nelbecino Mediterraneo. Roma 1985.

J. W. Hayes, Paphos. The Hellenistic and Roman Pottery, Paphos Bd. III. Nicosia 1991. 
76

Hayes 2008

Hellström 1965

Işın 2008

Jones 1950

Kenrick 1985

Korkut - Grosche 2007

Lund 1997

Meyer-Schlicthmann 1988

Meyza - Wiech 2013

Oransay 2012

Özdilek 2015

Özdilek 2016

Özdilek 2017

Pellegrino 2002

Poblome 1999

Rotroff 1997

Rückert 2003

Sackett 1992

Slane 1986

Slane 1990

Slane 1997

Takmer 2006

Tekkök - Biçken 1996

Uygun 2008

\section{Banu ÖZDILEK}

J. W. Hayes, Roman Pottery. Fine Ware Imports, The Athenian Agora XXXII, American School of Classical Studies 2008.

P. Hellström, Pottery of Classical and Later Date, Labraunda, Swedish Excavations and Researches. Bd. II 1, Lund 1965.

G. Işın, "The Building Complex on the Tepecik Acropolis at Patara". AnSt 60 (2010) 93-104.

F. F. Jones, "The Hellenistic and Roman Periods. The Pottery". Eds. H. Goldman, Excavations at Gözlükule, Tarsus. Bd. I (1950) 149-296.

P. M. Kenrick, The Fine Pottery, Bd. III 1, Princeton University Press (1985).

T. Korkut - G. Grosche, Das Bouleuterion von Patara. Versammlungsgebäude des lykischen Bundes, Patara 2/1. İstanbul 2007.

J. Lund, "The Distribution of Cypriot Sigillata as Evidence of Sea-trade Involing Cyprus". Eds. S. Swiny, R. L. Hohlfelder, H. W. Swiny, Res Maritimae Cyprus and the Eastern Mediterranean From Prehistory to Late Antiquity Proceedings of the Second International Symposium Cities of the Sea Nicosia, Cyprus. Georgia (1997) 201-2015.

C. Meyer-Schlichtmann, Die pergamenische Sigillata aus der Stadtgrabung von Pergamon. Mitte 2. Jh. v. Chr.- Mitte 2. Jh. n. Chr., PF 16. De Gruyter 1988.

H. Meyza - M. Wiech, Cypriot Sigillata from Kom el - Dikka Excavations in Alexandria Found Before 1986, Institut des Cultures Méditerranéenes et Oriantales de l'Académie Polonaise des Sciences Etudes et Travaux XXVI. (2013) 464-471.

B. S. A. Oransay, "Side 2009-2011 Yıllı Kazılarında Ele Geçen Doğu Sigillatası D (Kıbrıs Sigillatası) Seramikleri". Anadolu/Anatolia 28 (2012) 109-138.

B. Özdilek, "Andriake Sinagogu'ndan Seçilmiş Örneklerle Hellenistik ve Roma Dönemi Seramiklerine Genel Bir Bakış". CEDRUS III (2015) 89-117.

B. Özdilek, "2009-2012 Andriake Kazılarından Ele Geçen Unguentarium, Sişe, Lykion ve Mortar Örnekleri". OLBA XXIV (2016) 217-265.

B. Özdilek, "Andriake Sinagogu'ndan Ele Geçen DSA Grubu Seramikler" Cedrus $\mathrm{V}$ (2017) 337-395.

E. Pellegrino, "Le Materiel Céramique Issu des Fouilles Menées en 1995 et 2000 sur l'Acropole Lycienne de Xanthos". Anatolia Antiqua XII (2002) 45-260.

J. Poblome, Red Slip Ware, Typology and Chronology, SEMA II, Brepols Publishers 1999.

S. I. Rotroff, Hellenistic Pottery. Athenian and Imported Wheelmade Table Ware and Related Material, The Athenian Agora XXIX, Princeton 1997.

B. Rückert, "Zur Keramik aus den Weststadtgrabungen". KST 25 (2003) 60-61.

L. H. Sackett, "Roman Pottery. Knossos from Greek City to Roman Colony". Excavations at the Unexplored Mansion II. BSA. Suppl. 21. Athens 1992.

K. W. Slane, "Two Deposit from the Early Roman Cellar Building, Corinth". Hesperia 55 (1986) 271-318.

K. W. Slane, The Sanctuary of Demeter and Kore. The Roman Pottery and Lamps, Corinth XVIII Bd 2. New Jersey 1990.

K.W. Slane, The Hellenistic and Roman Pottery: The Fine Wares, Tell Anafa II, Ann Arbor, Mı 1997.

B. Takmer, Lex Portorii Provinciae Lyciae: Likya Eyaletleri Gümrük Yasası. Yayınlanmamış Doktora Tezi, Akdeniz Üniversitesi S.B.E. Antalya 2006.

B. Tekkök-Biçken, The Hellenistic and Roman Pottery from Troia: Second century B.C. to the Sixth Century A.D. Doktora Tezi . University of Missouri Columbia 1996.

Ç. Uygun, "Patara Tepecik Nekropolü'nden Italya ve Kıbrıs Sigillatası Örnekleri". III.- IV.Ulusal Arkeolojik Araştırmalar Sempozyumu, Anadolu / Anatolia Suppl. 2 (2008) 305-322. 
Uygun 2011

Winbladh 2015

Yener-Marksteiner 2012

Yener-Marksteiner 2013
Ç. Uygun, Tepecik Kırmızı Astarlı Seramikleri (MÖ 2. yy- MS 4 yy), Patara IV.2, İstanbul 2011.

M. L. Winbladh, Kıbrıs Aşk, Savaş, Kült. İstanbul 2015.

B. Yener-Marksteiner, "Frühkaiserzeitliche Sigillata der Weststadt grabung in Limyra 2002-2003" Eds. M. Seyer, 40 Jahre Grabung Limyra Akten des internationalen Symposions Wien, Wien, 371-386 (2012).

B. Yener-Marksteiner, "Vorläufige Ergebnisse der Untersuchungen der Keramik funde des Andriake Surveys" Eds. O. Henry, Carian Identity and Carian Language, 15-20. Bordeaux 2013. 